University of Nebraska - Lincoln

DigitalCommons@University of Nebraska - Lincoln

Biological Systems Engineering: Papers and

Publications

2017

Spatial and Temporal Changes in Maize and Soybean Grain Yield, Precipitation Use Efficiency, and Crop Water Productivity in the U.S. Great Plains

Meetpal S. Kukal

S. Irmak

Follow this and additional works at: https://digitalcommons.unl.edu/biosysengfacpub

Part of the Bioresource and Agricultural Engineering Commons, Environmental Engineering Commons, and the Other Civil and Environmental Engineering Commons

This Article is brought to you for free and open access by the Biological Systems Engineering at DigitalCommons@University of Nebraska - Lincoln. It has been accepted for inclusion in Biological Systems Engineering: Papers and Publications by an authorized administrator of DigitalCommons@University of Nebraska Lincoln. 


\title{
SPATIAL AND TEMPORAL CHANGES IN MAIZE AND SOYBEAN GRAIN YIELD, PRECIPITATION USE EFFICIENCY, AND CROP WATER PRODUCTIVITY IN THE U.S. GREAT PlAINS
}

\author{
M. Kukal, S. Irmak
}

\begin{abstract}
Sustainable agricultural utilization of the limited water resources demands improvements in understanding the changes in crop water productivity (CWP) in space and time, which is often presented as a potential solution to relieve the growing pressure on fresh water resources. In addition, crop yield needs to be studied in relation to precipitation received annually and during the growing season for its contribution to reduce irrigation water requirements, which is quantified through precipitation use efficiency (PUE). Hence, systematic quantifications, mapping, and analyses of large-scale CWP and PUE levels are needed. This study aims to quantify long-term (1982-2013) information on grain yield, PUE, and CWP for maize and soybean in the U.S. Great Plains counties and to map and analyze them. Multiple public data sources were used, including weather, satellite, and yield datasets for the 834 counties over a 32-year period. Long-term average maize grain yield ranged from 1.56 to $12.81 \mathrm{th} \mathrm{h}^{-1}$ with a regional average of $6.66 \mathrm{th} \mathrm{h}^{-1}$. Long-term average soybean grain yield ranged from 0.47 to $3.46 \mathrm{tha} \mathrm{h}^{-1}$ with an average of $2.17 \mathrm{t} \mathrm{ha} \mathrm{h}^{-1}$. About $87 \%$ and $89 \%$ of the counties in the region showed increasing trends in grain yield for maize and soybean, respectively, with regional average increasing trends for maize and soybean yield of 0.1014 and $0.0328 \mathrm{t} \mathrm{ha}^{-1}$ year $^{-1}$, respectively. The regional annual PUE (ANNPUE) and growing season PUE (GRSPUE) were 1.09 and $1.90 \mathrm{~kg} \mathrm{~m}^{-3}$, respectively, for maize and 0.32 and $0.55 \mathrm{~kg} \mathrm{~m}^{-3}$, respectively, for soybean. In addition, the regional average increasing trends in maize ANNPUE (exhibited by $88 \%$ of counties) and GRSPUE (exhibited by $85 \%$ of counties) were 0.0174 and $0.0316 \mathrm{~kg} \mathrm{~m}^{-3}$ year $^{-1}$. For soybean, regional average increasing trends in ANNPUE (exhibited by $91 \%$ of counties) and GRSPUE (exhibited by $87 \%$ of counties) were 0.0048 and $0.0081 \mathrm{~kg} \mathrm{~m}^{-3} \mathrm{year}^{-1}$. The magnitude of maize CWP varied from 0.30 to $2.97 \mathrm{~kg} \mathrm{~m}^{-3}$ with a regional average of $1.08 \mathrm{~kg} \mathrm{~m}^{-3}$, and soybean CWP varied from 0.15 to $0.67 \mathrm{~kg} \mathrm{~m}^{-3}$ with a regional average of $0.40 \mathrm{~kg} \mathrm{~m}^{-3}$. It was found that $79 \%$ and $86 \%$ of the counties showed positive trends in maize and soybean CWP, respectively, and the increasing trend magnitudes were 0.0144 and $0.0047 \mathrm{~kg}$ $m^{-3}$ year $^{-1}$. Pooled data from all counties and growing seasons were used to develop frequency distribution histograms to quantify the inter-annual variation and distribution characteristics. The level of CWP variability represented via maps revealed regions where opportunity exists for improvements in production system efficiency. A comprehensive understanding of the spatial and temporal patterns in these efficiency indices will provide a basis for decision-making in resource assessments, planning, evaluation, and investment by state and federal agencies and stakeholders.
\end{abstract}

Keywords. Agriculture, Climate, Evapotranspiration, Great Plains, Water productivity.

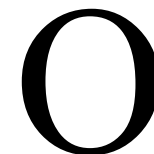
ne of the major challenges for the decades ahead is ensuring the food security for the rapidly growing population in a changing climate. Fulfilling the nutrition and food requirements for the projected 2 to 3 billion increase in population necessitates the allocation of major investments in the agricultural sector. At the same time, the pressure on the global water resources is increasing. Because drought and/or limited water resources

Submitted for review in September 2016 as manuscript number NRES 12072; approved for publication by the Natural Resources \& Environmental Systems Community of ASABE in March 2017.

The mention of the trade names or commercial products is for the information of the reader and does not constitute an endorsement or recommendation for use by the authors or their institutions.

The authors are Meetpal S. Kukal, ASABE Member, Graduate Research Assistant, and Suat Irmak, ASABE Member, Distinguished Professor, Department of Biological Systems Engineering, University of Nebraska-Lincoln, Nebraska. Corresponding author: Suat Irmak, 239 L.W. Chase Hall, University of Nebraska-Lincoln, Lincoln, NE 685830726, phone: 402-472-4865, e-mail: sirmak2@unl.edu. are major yield and productivity limiting factors of food and fiber production worldwide, a substantial portion of the increase in crop water productivity (CWP) to meet the food and fiber demands of the world's population will most likely stem from irrigated agriculture (Irmak, 2015a). Irrigated agriculture remains the largest water-consuming sector (FAO, 1994; Rosegrant et al., 2002), and irrigated agriculture has been rapidly increasing over the last several decades, approximately by two-fold between 1962 and 1998 (Ali and Talukder, 2008; Carruthers et al., 1997). Globally, irrigated agriculture contributes to $25 \%$ to $50 \%$ of food production (FAO, 1994). According to a 2003 FAO irrigation analysis conducted in 93 developing countries, an expected $81 \%$ increase in agricultural production by 2030 will come from irrigated areas. Due to the intensifying competition between the industrial and domestic sectors, less water will be available for agricultural production. By 2050, it is estimated that an additional $5,600 \mathrm{~km}^{3}$ of evapotranspired water per year will be required to meet the demand for food if no improvements in crop water productivity are made (Falkenmark and 
Rockstrom, 2004). Crop production areas will need to produce more crops with currently available water resources (Ali and Talukder, 2008). All these factors highlight that agricultural areas must increase production per drop of water to ensure food security sustainably (Zhang et al., 2003; Stanhill, 1986; Cao et al., 2007).

To aid in the development of a strategic framework for this challenge, the analyses of water use efficiency is crucially important. As of now, information on water use efficiency is often solely available from field experimentation, thus limiting the results to local climate conditions that vary from year to year and due to soil, crop, and water management practices followed at the particular site. Due to the labor involved, crop water consumption is difficult to measure routinely, which prevents extensive use of the concept of crop water productivity in policymaking and water management. Usually, the terms water use efficiency (WUE) and crop water productivity (CWP) are used to represent crop production per unit of water used (Howell, 1990; Perry, 2007; Perry et al., 2009; Keller and Seckler, 2005; Li et al., 2009; Irmak, 2015a, 2015b). CWP is an indicator for quantifying the impact of irrigation in potentially increasing productivity and can be a useful term to compare and judge different water management measures for a specific crop.

Because the term CWP is derived from the yield and water consumption of a particular crop, which are highly variable in both space and time, CWP has inherently high spatial and temporal variability. Various factors influence CWP, such as field, environmental variables, climate, management practices, and biophysical and socio-economic factors. Numerous researchers have addressed the variability in CWP due to factors including: (1) soil conditions, i.e., texture, erosion, salinity, and acidity (Landau et al., 1998; Ewert et al., 2002); (2) improvements in crop management due to adoption of better hybrids, varieties, and cultivars made possible through plant breeding and genetic modification (Evans, 1997; Amthor, 1998; Reynolds et al., 1999); (3) appropriate use of fertilizers (Garabet et al., 1998; Sexton et al., 1996); (4) influence of irrigation management practices (Stone et al., 1987; Irmak, 2015a, 2015b); (5) influence of planting dates (Fengrui et al., 2000; Irmak and Djaman, 2016), crop rotations, planting densities (Lang et al., 1956; Holt and Timmons, 1968; Lutz et al., 1971; Irmak and Djaman, 2016), climate variables (Irmak, 2015a, 2015b), and residue management (Tolk et al., 1999). Hence, the variability that occurs in CWP in both space and time in a particular region (e.g., the U.S. Great Plains) should be studied to gain a comprehensive understanding of the CWP dynamics at large scales.

To address the trends in CWP in any region, both in space and time, it is necessary to quantify the long-term CWP at large scales. Mo et al. (2005) used a process-based crop growth model (SVAT) to predict regional winter wheat and summer maize crop yield, water consumption, and WUE using weather data and remotely sensed data from NOAAAVHRR in the Hebei province of China. Li et al. (2008) used the SEBAL (Surface Energy Balance Algorithm for Land) model with NOAA remotely sensed data to determine water consumption of winter wheat and CWP and discussed spatial trends that were observed in the region. Chen et al.
(2010) used the APSIM model to simulate crop yield and water balance of a wheat-maize rotation and investigated the effects of climate variability (1961-2000) on CWP and water balance. Responses of wheat and maize crop yield and WUE to future climate change were investigated by Guo et al. (2010) using the CERES-Wheat and CERES-Maize models. In the Hai basin of China, Yan and $\mathrm{Wu}$ (2014) used satellite data and the CASA model to predict winter wheat evapotranspiration (ET) and aboveground biomass for the period 1984-2010 and carried out integrated spatial-temporal analyses. On the national scale, Liu et al. (2007) used GEPIC to simulate yield and CWP for winter wheat to model the role of irrigation in yield and crop water productivity in China. Mainuddin and Kirby (2009) used the CROPWAT model and provincial (administrative boundaries) data to estimate ET and yield, respectively, to analyze the spatial and temporal trends in water use efficiency in the lower Mekong basin. Immerzeel et al. (2008) investigated the Krishna River basin in southern India for evaluation of water use efficiency using the SEBAL and SWAT models. In central Asia, Abdullaev and Molden (2004) discussed spatial and temporal variability of water use efficiency during 1999-2001 in the Syr Darya basin. On a global scale, several researchers have explored the dynamics of CWP to identify regions with high potential to increase CWP while making use of several models and simulation tools. Liu et al. (2008) used the GEPIC model to simulate maize yield and CWP at a spatial resolution of 30 arc-minutes and observed that more than $80 \%$ of African countries have the potential to double their CWP. Brauman et al. (2013) used available global spatial datasets for 16 crops to analyze the contributions of CWP toward increasing water sustainability and food security. Among these various approaches, our study relies on a relatively simplified strategy, which involves quantification of CWP using national county-level yield statistics and crop water use estimates. The crop water use (crop ET) was estimated as the product of reference ET and crop coefficients, where reference ET was calculated from long-term weather records, and crop coefficients were estimated as a function of a satellitederived vegetative index.

Because both the amount and seasonal distribution of precipitation greatly influence crop evapotranspiration, irrigation requirement, and yield, the WUE of both irrigated and rainfed crop production is likely to be affected considerably by this crucial environmental variable. According to Turner (2004), the WUE of various crops is strongly impacted by growing season precipitation for potential yield, and several agronomic practices have been developed to capture and use growing season precipitation to enhance the WUE of various cropping systems. Hence, apart from discussing the contributions of irrigation, evapotranspiration, and crop yield when quantifying WUE, investigation of the water use of any cropping system in terms of seasonal precipitation amounts is indispensable. Some researchers have investigated the precipitation use efficiency (PUE) of various cropping systems (Greb et al., 1967; Greb, 1979; Smika, 1990; McGee et al., 1997; Farahani et al., 1998; Limon-Ortega et al., 2000; Hatfield et al., 2001; Peterson and Westfall, 2004; Fahong et al., 2004; Govaerts et al., 2006; Müller et al., 2009; Sharma et al., 2013; Irmak 2015b). Long-term re- 
search studies to explore the trends in PUE in different production regions are crucial, and our study aims to fulfill this need for the U.S. Great Plains.

This study focuses on the U.S. Great Plains, which shows high variability in air temperatures, precipitation, reference $\mathrm{ET}\left(\mathrm{ET}_{\mathrm{o}}\right)$, and aridity in both space and time, as discussed by Kukal and Irmak (2016a, 2016b). In addition, maize and soybean actual ET varies considerably throughout the region, as discussed by Kukal et al. (2017). Thus, it is anticipated that the magnitudes of CWP will show strong spatial tendencies as well. To our best knowledge, there has been no countybased direct quantification of CWP encompassing the multistate study region for a long-term period appropriate for discerning trends in time. Thus, the primary objective of this study is to quantify long-term crop (maize and soybean) water productivities and PUE for the Great Plains region from 1982 to 2013. The geographical trends obtained through the analysis were analyzed, and regions with high and low CWP were identified. Time series for both CWP and PUE were evaluated for investigation of temporal trends, and statistical significance was determined. All analyses were based primarily on county-scale datasets, although regional and statewide magnitudes were also quantified.

\section{Materials ANd Methods STUDY AREA}

The focus of this study was the central U.S., which is generally designated as the Great Plains (fig. 1). The area extends from the Canadian border in the north to Texas in the south, Wyoming and Colorado in the west, and Iowa in the east. Specifically, the area consists of nine states (Colorado, Iowa, Kansas, Nebraska, North Dakota, Oklahoma, South

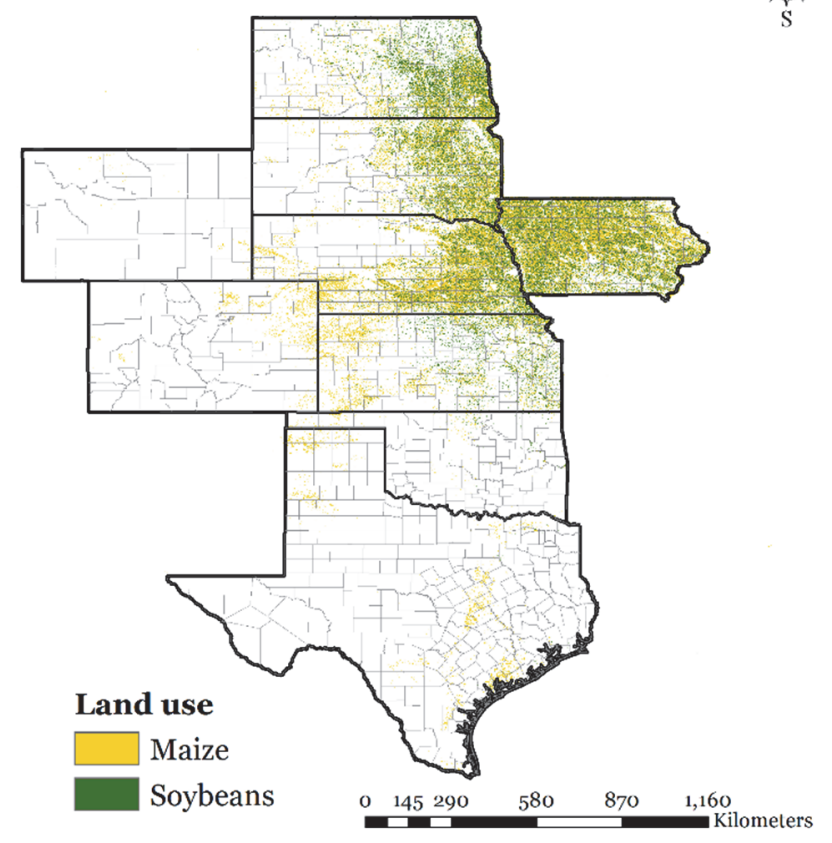

Figure 1. Map of the counties and maize and soybean growing regions in the study area.
Dakota, Texas, and Wyoming), which together comprise 834 counties. The total land area covered by these states is approximately 230 million ha, which is about $30 \%$ of the terrestrial area of the U.S. The area lies between dense forests in the east and mountains and deserts in the west (Rossum and Lavin, 2000). The topographical characteristic of the area are the vast, flat-to-rolling plains. The highest elevation throughout the region is in the Rocky Mountains in Colorado, and the lowest elevation is at the southern coastline in Texas. Cold air fronts from Canada in the north and the Rocky Mountains in the northwest along with warm and humid air masses flowing into the region from the Gulf of Mexico in the south govern the climatic conditions of the region (Irmak, 2010; Irmak et al., 2012b). This variability in climatic conditions is demonstrated by the existence of NOAA's 78 climatic divisions across the region. The land use categories in the region are primarily agricultural, including rangelands, prairies, and irrigated and rainfed farming of agronomic row crops such as maize, soybean, sorghum, alfalfa, wheat, sugar beets, and cotton (Mutiibwa and Irmak, 2013).

\section{SOURCES OF DATA}

The data used in this study primarily consisted of crop ET and yield datasets for the period 1982-2013. The crop ET datasets used in this study (i.e., maize and soybean ET) were adopted from the results of Kukal et al. (2017). These datasets were developed using the two-step approach, i.e., $\mathrm{ET}_{\mathrm{c}}$ $=\mathrm{ET}_{\mathrm{o}} \times K_{\mathrm{c}}$, where $\mathrm{ET}_{\mathrm{o}}$ was determined using a spatially and temporally calibrated form of the Hargreaves-Samani equation, as discussed by Kukal et al. (2017), and maize and soybean $K_{\mathrm{c}}$ were derived from satellite-retrieved NDVI. These datasets have been integrated with available land use datasets to identify areas that produce maize and soybean. Finally, magnitudes of maize and soybean seasonal ET for the period 1982-2013 were quantified at the county level so that the data were spatially consistent with the county-scale crop yield datasets.

Yield data were obtained from the USDA National Agricultural Statistics Service (USDA-NASS) for all counties reporting data for maize and soybean during the period 19822013. The county yield $\left(\mathrm{kg} \mathrm{ha}^{-1}\right)$ is defined as the ratio of the total harvested yield (in $\mathrm{kg}$ ) to the total harvested area (in ha) per year per county. The USDA-NASS yield data were reported in bushels per acre. These NASS yield datasets were already adjusted to a standard moisture content for a crop, i.e., $15.5 \%$ for maize and $12.5 \%$ for soybean, so that comparisons among yields could be made easily. For this study, conversions were made to kilograms per hectare using conversion factors of $62.77 \mathrm{~kg} \mathrm{ha}^{-1}$ for maize and $67.25 \mathrm{~kg} \mathrm{ha}^{-1}$ for soybean. Counties that did not report yield data for any particular year were excluded from our analysis. For the purpose of map development, various boundary datasets, such as county and state boundaries, were obtained from the USDA Geospatial Data Gateway for use in the ArcGIS environment.

\section{MAIZE AND SOYBEAN YIELDS}

Raw county-level yield data for maize and soybean were processed to develop organized crop yield information. The 
USDA-NASS collects county-level yield data by mail, telephone interview, personal interview, electronically, etc., conducts rigorous checks for consistency and accuracy, and reports yield data summarized by county using advanced statistical techniques so as to appropriately represent each county. For each county, a time series (1982-2013) of its reported maize and soybean yield data was constructed. Longterm average maize and soybean yields were computed for every county, and long-term average maps were developed to observe potential spatial trends in the maize and soybean yield distribution over the entire study region.

\section{MaIze ANd Soybean Crop Water USE}

Crop water use was computed on spatial scales for both crops by integrating ground-based and satellite observational data. Daily grass reference ET $\left(\mathrm{ET}_{\mathrm{o}}\right)$ was determined at 800 weather stations distributed over the study region for the period 1982-2013 using a spatially and temporally calibrated Hargreaves-Samani equation (Kukal et al., 2017). Daily $\mathrm{ET}_{\mathrm{o}}$ values at each station were summed to obtain monthly $\mathrm{ET}_{\mathrm{o}}$ for the 32-year period. Interpolation procedures (inverse distance weighting) were applied in ArcGIS (ver. 10.2, ESRI, Redlands, Cal.) to monthly $\mathrm{ET}_{0}$ at the stations to generate spatial surfaces for each month and year. In addition, $K_{\mathrm{c}}$-NDVI linear models were developed and validated using observed $K_{\mathrm{c}}$ data from BREBS sites 6 and 10 of the NEBFLUX (Nebraska Water and Energy Flux Measurement, Modeling and Research Network) project (Irmak, 2010) and NDVI data from the MODIS $250 \mathrm{~m}$ product. NEBFLUX operates 11 Bowen ratio energy balance system (BREBS) and eddy covariance systems over surfaces including subsurface drip and center-pivot irrigated and rainfed maize and soybean rotations under no-till and disk-till practices, irrigated and rainfed grasslands, irrigated alfalfa, irrigated seed maize and cover crop rotation, phragmites-dominated cottonwood and peach-leaf willow riparian zone, rainfed winter wheat, irrigated black turtle bean, irrigated popcorn, irrigated grain sorghum, and surface drip irrigated vineyard. Some of the flux towers have been operating since 2004. The flux towers measure all surface energy balance components, including latent heat flux $\left(\mathrm{ET}_{\mathrm{c}}\right)$, soil heat flux $(G)$, sensible heat flux $(H)$, net radiation $\left(R_{n}\right)$, surface albedo, soil temperature, soil water content every $0.30 \mathrm{~m}$ down to $1.8 \mathrm{~m}$ as well as numerous other variables on an hourly basis throughout calendar year, including dormant seasons. In addition, agronomic practices data, stomatal resistance, leaf area index, plant height, and other supporting data are measured at most of the NEBFLUX tower sites. Measurements also include vegetation physiology, yield, and biomass production through extensive field campaigns. Detailed characteristics of the instrumentation, experimental setup, measurement details, soil and crop and management practices, and other information for each NEBFLUX tower site are provided by Irmak (2010). Because the NDVI data had a spatial resolution of $250 \mathrm{~m}$, the NDVI value represented the average vegetation (crop) cover of the entire pixel. It was ascertained that the pixels containing the BREBS sites were specifically composed of the particular single crop for which the model was being developed. In addition, the usual field dimensions are greater than $250 \mathrm{~m}$ by $250 \mathrm{~m}$, which strength- ened our selection of $250 \mathrm{~m}$ NDVI data for model development. These models were used to develop spatial $K_{\mathrm{c}}$ from spatial NDVI data derived from AVHRR (1982-1999) and MODIS (2000-2013) satellite imagery for each month of the growing season.

Because the aim was to develop crop-specific spatial $K_{\mathrm{c}}$, it is crucial to identify spatial locations in the study region that are covered by the vegetative surfaces of interest (maize and soybean). The pixels depicting maize and soybean crops had to be extracted from spatial crop coefficient datasets, which required extensive and high-quality land use datasets. In this study, land use information was obtained from two different sources, which differed in time period and detail. The land use datasets for the period 2009-2013 were obtained from the USDA Cropland Data Layer (http://nassgeodata.gmu.edu). For 1992, 2001, and 2006, the datasets were obtained from the Multi-Resolution Land Characteristics Consortium (http://www.mrlc.gov). Through this exercise, it was ascertained that the $K_{\mathrm{c}}$ maps represent only maize and soybean $K_{\mathrm{c}}$, and no other summer crops. Both of these spatial datasets, namely monthly $\mathrm{ET}_{\mathrm{o}}$ and monthly $K_{\mathrm{c}}$ for each growing season in the period 1982-2013, were multiplied to derive spatial actual maize and soybean ET. The monthly ET layers were summed for the growing season (i.e., May to September) to obtain growing season actual ET. Land use datasets published during the study period were used to exclude non-crop pixels in the maize and soybean spatial ET layers. Finally, county-level actual ET was calculated for each maize and soybean producing county using the zonal statistics tool in ArcGIS 10.2. A detailed description of the methodologies used for quantification of crop ET is provided by Kukal et al. (2017).

The county-level data for maize and soybean ET were organized using spreadsheet tools, and long-term averages were calculated. Long-term spatial maps were developed to better represent the spatial distribution of maize and soybean ET over the region. Counties qualified for further analysis only when complete datasets were available for both crop yield and ET for a particular year.

\section{Precipitation Use EfFiciency}

Irrigation water requirements, at least for some regions, can be considerably reduced if rainwater can be captured and stored during the growing and/or non-growing (dormant) seasons. Several effective irrigation management strategies can be adopted for improved storage of precipitation. This can lead to increased contribution of growing and dormant season precipitation and consequently result in reduction in irrigation water requirements. Various crop production regions can be investigated and evaluated for precipitation water use efficiency. In this study, we quantified annual and growing season precipitation use efficiencies (ANNPUE and GRSPUE) following Irmak (2015b) at county scale for both maize and soybean for the areas producing these crops following methods outlined by Irmak (2015b). ANNPUE is commonly defined as the ratio of aboveground net primary production (grain yield and/or dry matter production, $\mathrm{t} \mathrm{ha}^{-1}$ ) to annual precipitation (mm). Similarly, GRSPUE is defined as the ratio of aboveground net primary production (grain yield and/or dry matter production, $\mathrm{t} \mathrm{ha}^{-1}$ ) to growing season 
precipitation $(\mathrm{mm})$. These terms are described by equations 1 and 2:

$$
\begin{gathered}
\text { ANNPUE }=\frac{Y_{\text {maize } / \text { soybean }}}{\text { Annual precipitation }} \\
\text { GRSPUE }=\frac{Y_{\text {maize } / \text { soybean }}}{\text { Growing season precipitation }}
\end{gathered}
$$

where $Y_{\text {maize/soybean }}$ is the county averaged yield for maize or soybean $\left(\mathrm{t} \mathrm{ha}^{-1}\right)$, and annual and growing season precipitation is in mm. For the purpose of this study, we considered annual precipitation as the total precipitation received from January 1 to December 31 for each year, and growing season precipitation was the total precipitation received from May 1 to September 30, following Irmak (2015b).

Both of these variables (ANNPUE and GRSPUE) were quantified for each county and each year or growing season by dividing the yield for a particular county and year (from USDA-NASS) by the precipitation received by that county in that year. Magnitudes of ANNPUE and GRSPUE for both crops were calculated and mapped for spatial visualization of trends over the region. Time series were constructed for each county for both variables to be used in temporal trend analysis for understanding the changes that have occurred over time in different areas.

\section{Crop Water Productivity}

The CWP values at county scale for the period 1982-2013 were calculated to evaluate the efficiency response of maize and soybean producing areas and the potential changes that have occurred with time. CWP was computed as the ratio of grain yield to actual crop (maize and soybean) evapotranspiration:

$$
\mathrm{CWUE}=\frac{Y_{\text {maize }} / \text { soybean }}{{\mathrm{Crop} \mathrm{ET}_{\text {maize }} / \text { soybean }}}
$$

where $Y_{\text {maize/soybean }}$ is the county-averaged yield for maize or soybean $\left(\mathrm{t} \mathrm{ha}^{-1}\right)$, and crop $\mathrm{ET}_{\text {maize/soybean }}$ is county-averaged crop ET for either crop (mm). CWP was calculated for each county in the study area and each year in the study period for each crop. Similar to ANNPUE and GRSPUE, datasets were developed for map development and temporal trend analysis.

\section{Statistical Procedures USEd IN \\ TEMPORAL TREND ANALYSES \\ Mann-Kendall Trend Test}

The county-specific values for all variables were quantified for the 32-year period, and time series were constructed. To identify temporal trends in these variables and to investigate their statistical significance, a set of statistical tests was applied. The Mann-Kendall test (Kendall's tau) is one of the most widely accepted non-parametric tests for detecting significant trends in a time series (Mann, 1945; Kendall, 1975). The null hypothesis $\left(\mathrm{H}_{\mathrm{o}}\right)$ stated by the $\mathrm{M}-\mathrm{K}$ test is non-existence of a trend in the time series of the observational data of $n$ independent and identically distributed random variables. On the other hand, the alternative hypothesis $\left(\mathrm{H}_{1}\right)$ is that a monotonic trend exists in $X$. The test statistic $S$ is asymptotically normal, has a mean zero and a variance, and is computed by equation 6 (after computations using eqs. 4 and 5):

$$
S=\sum_{k=1}^{n-1} \sum_{j=k+1}^{n} \operatorname{sgn}\left(x_{j}-x_{k}\right)
$$

where $x_{j}$ and $x_{k}$ are the time series observations in chronological order, and $n$ is the length of the dataset.

$$
\begin{gathered}
\operatorname{sgn}\left(x_{j}-x_{k}\right)=\left\{\begin{array}{cl}
+1 & \text { if }\left(x_{j}-x_{k}\right)>0 \\
0 & \text { if }\left(x_{j}-x_{k}\right)=0 \\
-1 & \text { if }\left(x_{j}-x_{k}\right)<0
\end{array}\right. \\
\operatorname{Var}(S)=\frac{n(n-1)(2 n+5)-\sum_{t} t(t-1)(2 t+5)}{18}
\end{gathered}
$$

where $t$ represents the extent of a given tie, and $\Sigma_{t}$ is the summation over all ties. In cases where the sample size $(n)$ is $>10$, the standard normal variable $Z$ is computed using equation 7:

$$
Z=\left\{\begin{array}{cc}
\frac{S-1}{\sqrt{\operatorname{Var}(S)}} & \text { if } S>0 \\
0 & \text { if } S=0 \\
\frac{S+1}{\sqrt{\operatorname{Var}(S)}} & \text { if } S<0
\end{array}\right.
$$

Increasing and decreasing trends are represented by positive and negative values of $Z$, respectively. To investigate the increasing or decreasing monotonic trends at the $\alpha$ significance level, the null hypothesis was rejected when an absolute value of $Z$ greater than $Z_{1-\alpha / 2}$ was detected, where $Z_{1-}$ $\alpha / 2$ was obtained from the standard normal cumulative distribution tables. In this study, detection of any increasing or decreasing trends was performed at significance levels of $\alpha=0.01$ and $\alpha=0.05$.

\section{Sen's Slope Estimator}

After determining whether a linear trend is present or not in a particular time series, a simple non-parametric procedure, developed by Sen (1968), was applied to calculate the true magnitude of the slope of the linear trend. This estimate is given by the Theil-Sen estimator as:

$$
b=\operatorname{Median}\left(\frac{x_{j}-x_{z}}{j-1}\right)
$$

Considering an annual time series, $b$ denotes the annual increment under the hypothesis of a linear trend. The magnitude of $b$ provides the real slope of the annual trend and can vary slightly from the slope obtained from linear regression.

\section{RESULTS AND DISCUSSION}

\section{SPATIAL AND TEMPORAL TRENDS IN YIELd}

The regional average maize yield was 6.66 ton $\mathrm{ha}^{-1}$, which 
was averaged over 680 counties for which long-term datasets were available. The long-term average maize yield across the region varied from a minimum of 1.56 ton ha $\mathrm{h}^{-1}$ in Galveston County, Texas, to a maximum value of 12.81 ton $\mathrm{ha}^{-1}$ in Wheeler County, Texas. The standard deviation (SD) observed in maize yield across the region was 2.1 ton ha-1. The highest maize yields were observed in the High Plains region of Texas, followed by counties in southwest region of Kansas (fig. 2). Statewide averaged maize yields were computed from county-level yield data and analyzed to compare statewide yields. On a statewide average scale, Iowa had the highest maize yield, followed by Nebraska, Colorado, Kansas, Wyoming, Texas, South Dakota, Oklahoma, and North Dakota. This implies that although the counties with the highest yields were in Texas and Kansas, on a statewide basis, Iowa and $\mathrm{Ne}$ braska had the highest yields overall. The magnitudes of statewide maize yields and other descriptive statistics are shown in table 1 . The maximum and minimum SD values were observed in Iowa and Colorado, respectively. However, the highest coefficient of variation $(\mathrm{CV})$ was observed in North Dakota, while the lowest was observed in Colorado.

The regional average soybean yield (fig. 3) was 2.17 ton $\mathrm{ha}^{-1}$, which was averaged over 562 counties for which longterm datasets were available. The long-term average soybean yield across the region varied from a minimum of 0.47 ton $\mathrm{ha}^{-1}$ in Mercer County, North Dakota, to a maximum of 3.46 ton $\mathrm{ha}^{-1}$ in Hamilton County, Nebraska. The SD of soybean yield across the region was 0.64 ton $\mathrm{ha}^{-1}$. The regions with the highest observed long-term average soybean yield were south central and central Nebraska, Iowa, and southwest and south central Kansas. On a statewide basis, the highest statewide average soybean yield was observed in

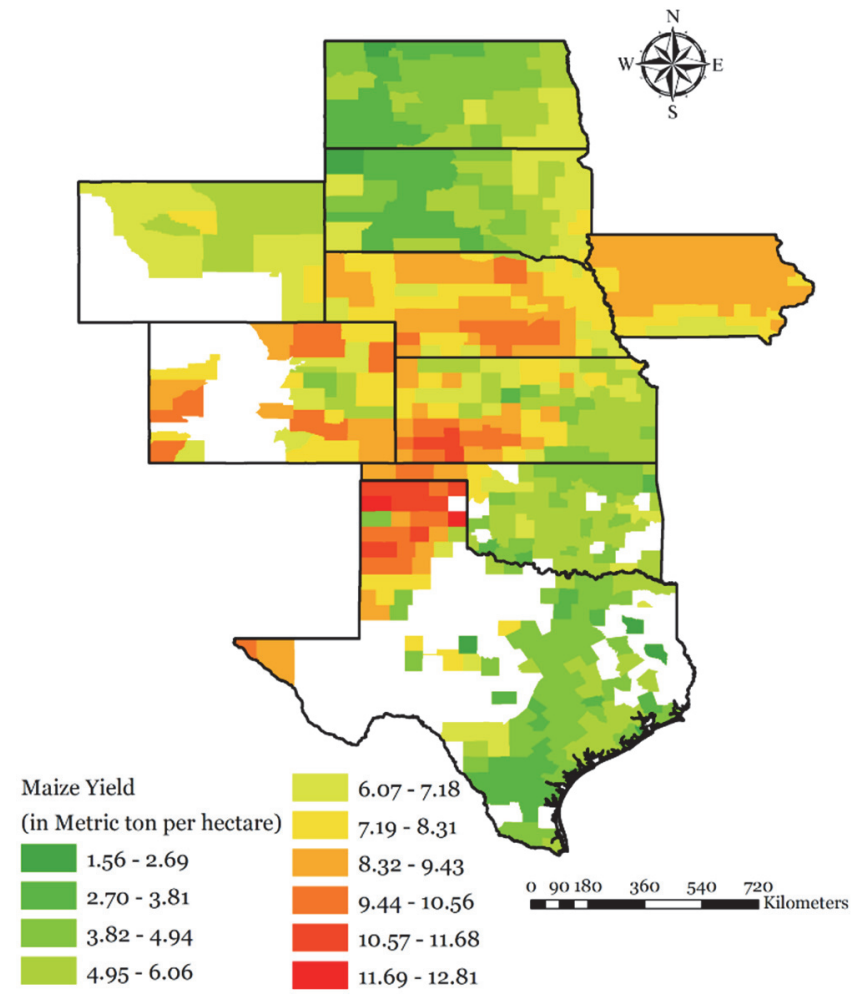

Figure 2. Long-term (1982-2013) mean maize yield on a county basis $\left(\right.$ ton ha $\left.\mathbf{~ h}^{-1}\right)$.
Table 1. Descriptive statistics of statewide average maize and soybean yields (ton ha-1).

\begin{tabular}{lccccc}
\hline & \multicolumn{5}{c}{ Statistic } \\
\cline { 2 - 6 } Crop and State & Mean & Max. & Min. & SD & CV \\
\hline Maize & & & & & \\
Iowa & 8.64 & 11.26 & 4.83 & 1.71 & 0.20 \\
Nebraska & 8.30 & 10.89 & 6.05 & 1.22 & 0.15 \\
Colorado & 8.06 & 9.76 & 6.93 & 0.68 & 0.08 \\
Kansas & 7.02 & 9.14 & 5.09 & 0.96 & 0.14 \\
Wyoming & 6.22 & 8.97 & 5.02 & 1.10 & 0.18 \\
Texas & 5.81 & 8.09 & 3.96 & 0.98 & 0.17 \\
S. Dakota & 5.40 & 8.85 & 3.51 & 1.40 & 0.26 \\
Oklahoma & 5.37 & 7.31 & 2.98 & 1.01 & 0.19 \\
N. Dakota & 4.70 & 7.04 & 2.32 & 1.35 & 0.29 \\
\hline Soybean & & & & & \\
Iowa & 2.89 & 3.50 & 1.99 & 0.44 & 0.15 \\
Nebraska & 2.76 & 3.67 & 1.94 & 0.49 & 0.18 \\
Kansas & 2.19 & 2.98 & 1.42 & 0.37 & 0.17 \\
S. Dakota & 1.85 & 2.88 & 1.44 & 0.39 & 0.21 \\
Texas & 1.85 & 2.44 & 1.26 & 0.30 & 0.16 \\
N. Dakota & 1.52 & 2.30 & 0.85 & 0.42 & 0.28 \\
Oklahoma & 1.52 & 2.08 & 0.86 & 0.33 & 0.22 \\
\hline
\end{tabular}

Iowa, followed by Nebraska, Kansas, South Dakota, Texas, North Dakota, and Oklahoma. No long-term data were available for any counties in Colorado and Wyoming. The statewide average soybean yields are shown in table 1 . The maximum and minimum SD values were observed in $\mathrm{Ne}-$ braska and Texas, respectively. The highest CV was observed in North Dakota, while the lowest was observed in Iowa.

Increasing trends in maize and soybean yields were observed during the study period for most of the counties in Nebraska and other states. For each county in the study area, figure 4 shows whether the temporal trend is increasing or decreasing and whether the trend is large enough to be sig-

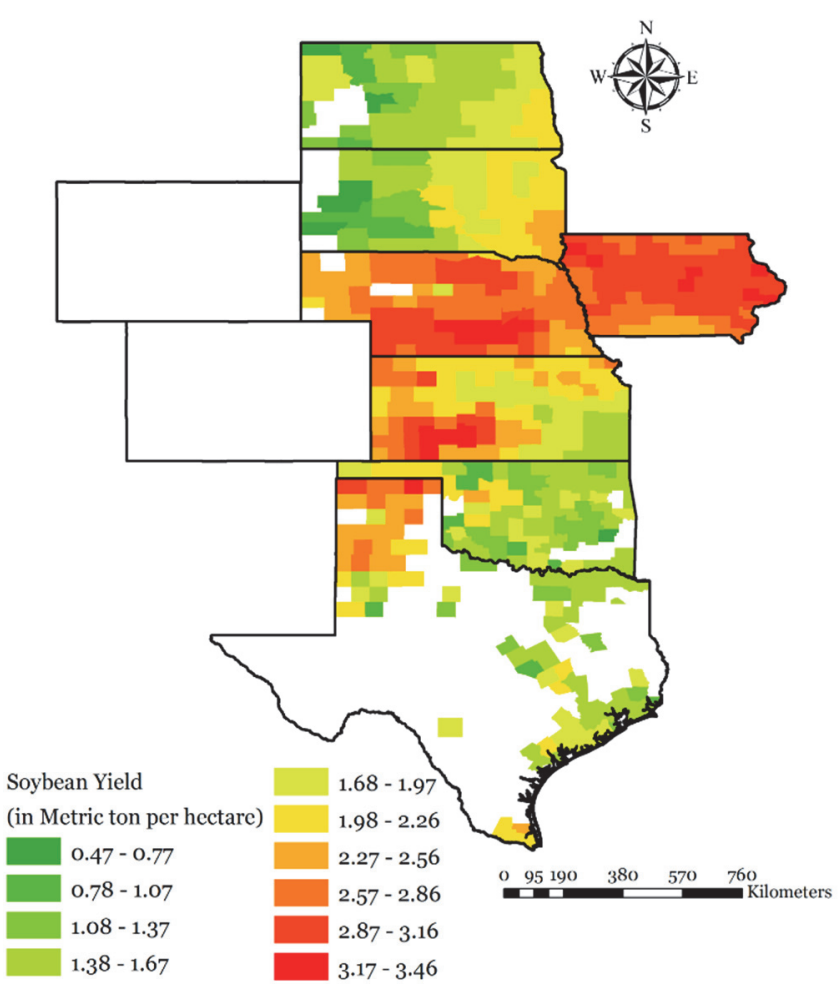

Figure 3. Long-term (1982-2013) mean soybean yield on a county basis $\left(\right.$ ton ha' $\left.{ }^{-1}\right)$. 

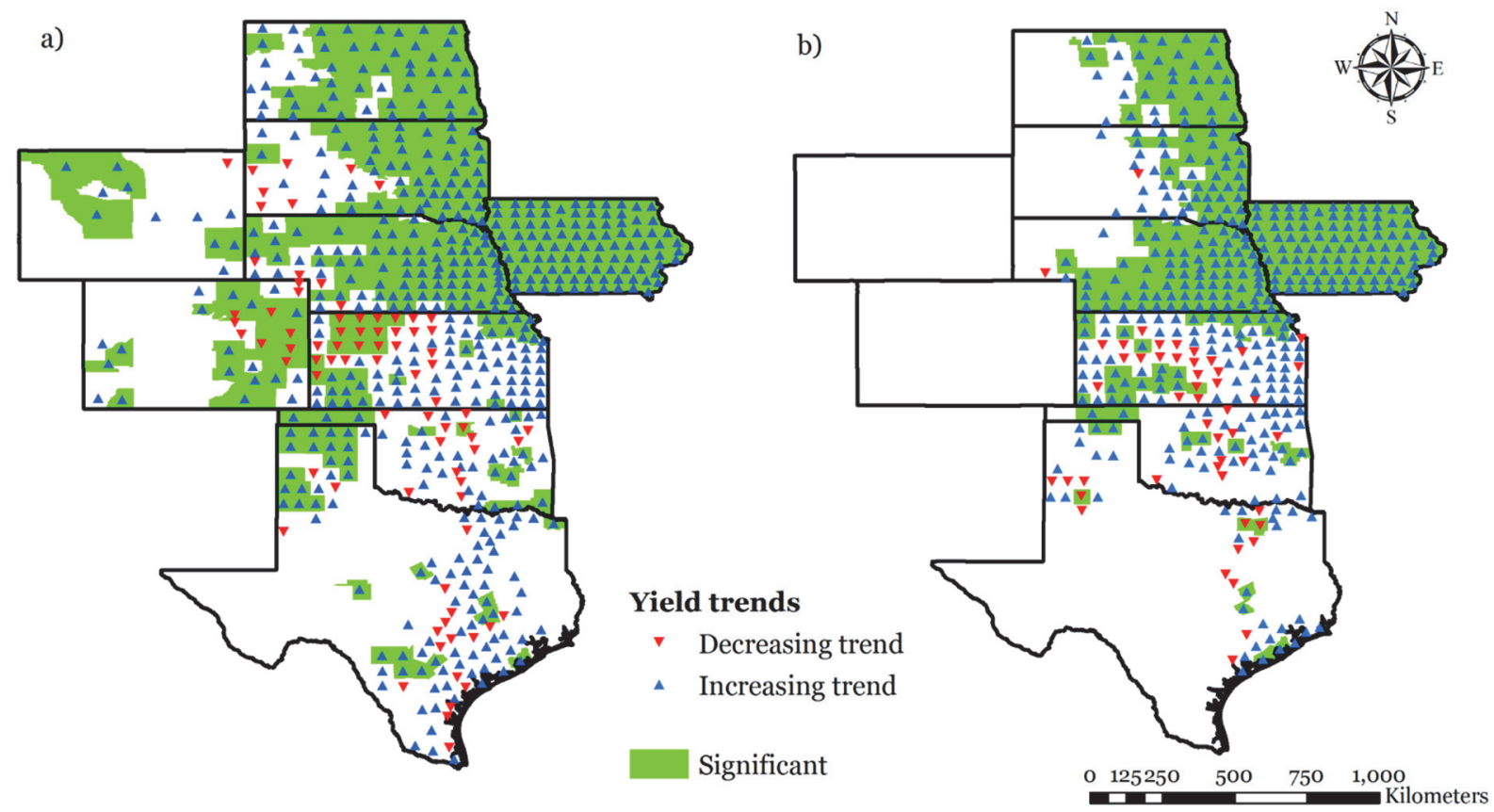

Figure 4. Temporal trends in (a) maize yield and (b) soybean yield (ton $\mathrm{ha}^{-1}$ ) during the period 1982-2013 for the study region counties.

nificant by statistical definition. In these maps, the blue upright arrows represent increasing (positive) trends, while the red inverted arrows indicate decreasing (negative) trends. Counties with green background indicate that the trend for the county is statistically significant at $\alpha=0.05$, as distinguished from counties with insignificant trends (counties with a white background). Non-significant trends are still crucial to report because these trends can have potential implications for agricultural crop production by affecting yields, irrigation, disease risks, pests, etc., even though they do not qualify as trends in statistical terms. The proportion of counties that showed increasing trends in maize yield was $87 \%$, while $89 \%$ of counties showed increasing trends in soybean yields, and the remainder of the counties showed decreasing trends. For maize yield, counties in northwest, north central, central, and west central Kansas and in the Platte drainage basin, Kansas drainage basin, and Arkansas drainage basin in Colorado showed significant decreasing trends. Among other decreasing trends in the region were some counties in South Dakota, Nebraska, Wyoming, Oklahoma, and Texas. Similarly, for soybean yield, apart from a few counties in Texas that had significant decreasing trends, all other decreasing trends were found in Oklahoma, Texas, and Kansas and were insignificant. Increasing trends for maize yield ranged from $0.4 \mathrm{~kg} \mathrm{ha}^{-1}$ year $^{-1}$ (increased by $0.5 \%$ ) to $466.4 \mathrm{~kg} \mathrm{ha}^{-1}$ year $^{-1}$ (increased by $223 \%$ ) with a regional average of $101.4 \mathrm{~kg} \mathrm{ha}^{-1}$ year-1 (increased by $55 \%$ ). Decreasing trends ranged from $0.9 \mathrm{~kg} \mathrm{ha}^{-1}$ year $^{-1}$ (decreased by $0.3 \%$ ) to $234.9 \mathrm{~kg} \mathrm{ha}^{-1}$ year $^{-1}$ (decreased by $100 \%$ ) with a regional average of $53.6 \mathrm{~kg} \mathrm{ha}^{-1}$ year-1 (decreased by $29 \%$ ). On the other hand, increasing trends for soybean yield ranged from $0.4 \mathrm{~kg} \mathrm{ha}^{-1}$ year $^{-1}$ (increased by $0.8 \%$ ) to 153.8 $\mathrm{kg} \mathrm{ha}^{-1}$ year $^{-1}$ (increased by $406 \%$ ) with a regional average of $32.8 \mathrm{~kg} \mathrm{ha}^{-1}$ year $^{-1}$ (increased by $52.7 \%$ ). Likewise, the decreasing trends ranged from $1 \mathrm{~kg} \mathrm{ha}^{-1}$ year $^{-1}$ (decreased by
$1.2 \%$ ) to $56.4 \mathrm{~kg} \mathrm{ha}^{-1}$ year $^{-1}$ (decreased by $122 \%$ ) with a regional average of $16.4 \mathrm{~kg} \mathrm{ha}^{-1}$ year-1 $^{-1}$ (decreased by $26.4 \%$ ). Therefore, the regional percentage for increasing trends in maize was $2.3 \%$ greater than that for soybean. Similar increases in grain yield were reported by Irmak and Sharma (2015) for Nebraska during the period 1986-2009. They found that grain yield increased by $166 \mathrm{~kg} \mathrm{ha}^{-1}$ year $^{-1}$ for irrigated maize and by $84 \mathrm{~kg} \mathrm{ha}^{-1}$ year $^{-1}$ for rainfed maize. These yield increases for irrigated and rainfed soybean were 50 and $30 \mathrm{~kg} \mathrm{ha}^{-1}$ year $^{-1}$, respectively.

The overall increases in maize and soybean yields are the result of several technological advances. These include plant genetics, improved machinery, increased dependence on irrigation and agrochemicals to improve soil nutrient status and pest resistance, soil and crop management, a prolonged photosynthetic period (Tollenaar and $\mathrm{Wu}, 1999)$, regional climate change and variability (Lobell and Asner, 2003), and a combination of all the aforementioned factors. On the other hand, declines in yield can be possibly due to a mixture of biophysical and socioeconomic factors. According to Ray et al. (2012), increased adoption of no-till practice by producers in the semi-arid areas of the Great Plains and intensified crop rotations are a probable cause of yield stagnations in the region. For instance, the negative trends in maize yield in some Kansas counties may be due to wheat-maize rotations, as opposed to a fallow period following wheat, which does not allow restoration of soil fertility. Other factors may include absence of significant irrigation infrastructure, prioritization of livestock over grain crops, lack of availability of suitable high-yielding crop varieties, lack of farmer expertise in appropriate agronomic practices, or lack of established agricultural research and investment. Although yield declines or stagnation have been observed, this does not necessarily translate into lower income and profits because an increase in the number of crops per cropping cycle or intercropping 
with other crops can increase the net food supply and hence farm incomes.

\section{Histograms of Yield Frequency Distributions}

A large degree of inter-annual variation was observed among maize and soybean yields as affected by variability in precipitation and other climatic variables. Direct and indirect effects of weather conditions were the primary reasons for this variability. To assess the changes in maize and soybean yields in a quantitative way, frequency distribution histograms of maize and soybean yields were developed (fig. 5). These histograms show the range and distribution of yields across the Great Plains. A total of 17,793 observation data points for maize and 13,288 observation data points for soybean were used to develop the frequency distribution histograms. Because the numbers of total observations for maize and soybean were unequal, the frequency distributions are represented as percentages of the total observations for each crop for improved interpretation. Maize yield ranged from 0.3 to 14.8 ton $\mathrm{ha}^{-1}$ with a peak frequency for the range 8 to 8.5 ton $\mathrm{ha}^{-1}$. Soybean yield ranged from 0.20 to 4.61 ton $\mathrm{ha}^{-1}$ with a peak frequency for the range of 2 to 2.5 ton ha $\mathrm{h}^{-1}$.

To further investigate the variation in crop yield during 1982-2013, we calculated the skewness statistic for the crop yield for each year (table 2) to quantify the variation in frequency distribution over the study period. In recent years, large negative values of skewness were observed for both maize and soybean, which represents large frequencies of higher yields. However, positive values of skewness signify that the histogram distribution is more skewed toward lower yield in those particular years. For example, the skewness values were positive during 2002 and negative, but small, during 2012. This might be because those years were extremely dry, with region average growing season precipitation of only 290 $\mathrm{mm}$ (16\% lower than long-term average) in 2002 and $238 \mathrm{~mm}$ (31\% lower than long-term average) in 2012. Below-normal precipitation might have played an important role in the lower yields, especially in areas with rainfed crop production. Because our analysis was based on a large-scale average rather than distinguishing between irri-gated and rainfed crops, it was difficult to consider the effect of precipitation on crop
Table 2. Skewness for yield, annual precipitation use efficiency (ANNPUE), growing season precipitation use efficiency (GRSPUE), and crop water productivity (CWP) for maize and soybean.

\begin{tabular}{|c|c|c|c|c|c|c|c|c|}
\hline \multirow[b]{3}{*}{ Year } & \multicolumn{8}{|c|}{ Skewness } \\
\hline & \multicolumn{2}{|c|}{ Yield } & \multicolumn{2}{|c|}{ ANNPUE } & \multicolumn{2}{|c|}{ GRSPUE } & \multicolumn{2}{|c|}{ CWP } \\
\hline & Maize & Soy & Maize & Soy & Maize & Soy & Maize & Soy \\
\hline 1982 & -0.16 & -0.55 & 1.38 & 1.37 & 1.50 & 0.73 & 0.58 & -0.40 \\
\hline 1983 & 0.15 & -0.19 & 1.29 & 1.59 & 1.95 & 1.51 & 0.83 & -0.10 \\
\hline 1984 & 0.04 & 0.00 & 1.14 & 2.04 & 1.14 & 1.51 & 0.55 & 0.44 \\
\hline 1985 & -0.38 & -0.84 & 1.03 & 1.68 & 1.56 & 0.78 & 0.45 & -0.43 \\
\hline 1986 & -0.23 & -0.69 & 1.41 & 1.58 & 1.86 & 0.73 & 0.61 & -0.39 \\
\hline 1987 & 0.02 & -0.22 & 1.01 & 1.61 & 1.67 & 0.04 & 0.81 & -0.05 \\
\hline 1988 & 0.31 & -0.01 & 1.27 & 1.81 & 1.92 & 0.93 & 0.83 & 0.87 \\
\hline 1989 & -0.09 & -0.30 & 1.04 & 1.60 & 3.01 & 0.89 & 0.46 & 0.07 \\
\hline 1990 & -0.27 & -0.21 & 0.82 & 1.66 & 1.65 & 1.56 & 0.27 & 0.07 \\
\hline 1991 & -0.02 & -0.12 & 1.06 & 1.66 & 1.53 & 0.83 & 0.67 & 0.38 \\
\hline 1992 & -0.14 & -0.80 & 1.44 & 1.63 & 1.59 & 0.30 & 0.11 & -0.58 \\
\hline 1993 & 0.57 & -0.22 & 1.88 & 1.15 & 2.49 & 1.83 & 0.85 & -0.18 \\
\hline 1994 & -0.17 & -0.56 & 0.95 & 2.14 & 2.58 & 0.62 & 0.28 & -0.16 \\
\hline 1995 & 0.25 & 0.14 & 1.54 & 1.40 & 1.87 & 0.01 & 0.81 & 0.08 \\
\hline 1996 & -0.31 & -0.41 & 1.21 & 1.53 & 3.09 & -0.12 & 0.11 & -0.23 \\
\hline 1997 & 0.25 & -0.34 & 0.75 & 1.95 & 1.35 & -0.09 & 1.23 & -0.01 \\
\hline 1998 & -0.41 & -0.44 & 1.09 & 2.06 & 3.01 & 1.57 & -0.10 & -0.37 \\
\hline 1999 & 0.04 & -0.24 & 1.77 & 1.83 & 1.95 & 0.37 & 0.98 & -0.19 \\
\hline 2000 & -0.24 & -0.14 & 2.01 & 2.35 & 2.42 & 0.75 & 0.97 & -0.12 \\
\hline 2001 & -0.14 & -0.24 & 2.22 & 1.90 & 2.90 & 0.70 & 0.55 & -0.21 \\
\hline 2002 & 0.07 & 0.05 & 1.58 & 2.30 & 2.43 & 1.52 & 0.74 & 0.39 \\
\hline 2003 & -0.14 & 0.46 & 1.25 & 2.07 & 1.78 & 1.30 & 0.34 & 0.91 \\
\hline 2004 & -0.35 & -0.58 & 1.03 & 1.96 & 2.71 & 0.28 & 0.87 & -0.41 \\
\hline 2005 & -0.12 & -0.23 & 1.07 & 2.10 & 1.53 & 0.43 & 0.44 & -0.21 \\
\hline 2006 & -0.13 & -0.38 & 1.43 & 2.16 & 2.98 & 0.34 & 0.95 & -0.02 \\
\hline 2007 & -0.14 & -0.52 & 1.86 & 1.93 & 2.15 & 0.91 & 0.56 & -0.40 \\
\hline 2008 & -0.46 & -0.11 & 2.21 & 1.98 & 4.42 & 0.31 & 0.75 & -0.08 \\
\hline 2009 & -0.86 & -0.66 & 0.74 & 2.27 & 0.78 & 0.19 & -0.93 & -0.58 \\
\hline 2010 & 0.00 & -0.19 & 1.67 & 1.68 & 2.17 & 1.41 & 0.46 & -0.36 \\
\hline 2011 & -0.51 & -0.47 & 1.74 & 2.24 & 3.53 & 1.97 & 0.52 & -0.53 \\
\hline 2012 & -0.02 & -0.17 & 1.59 & 3.13 & 1.42 & 1.70 & 1.18 & 0.44 \\
\hline 2013 & -0.26 & -0.20 & 1.67 & 2.15 & 1.49 & 0.56 & 0.69 & 0.03 \\
\hline
\end{tabular}

yield in rainfed settings. Overall, negative values of skewness were observed for most of the years in the study period.

\section{SPATIAL AND TEMPORAL TRENDS IN PRECIPITATION USE EFFicienCY Maize PUE}

Annual and growing season PUE values for a particular county and year were calculated as the ratio of reported crop

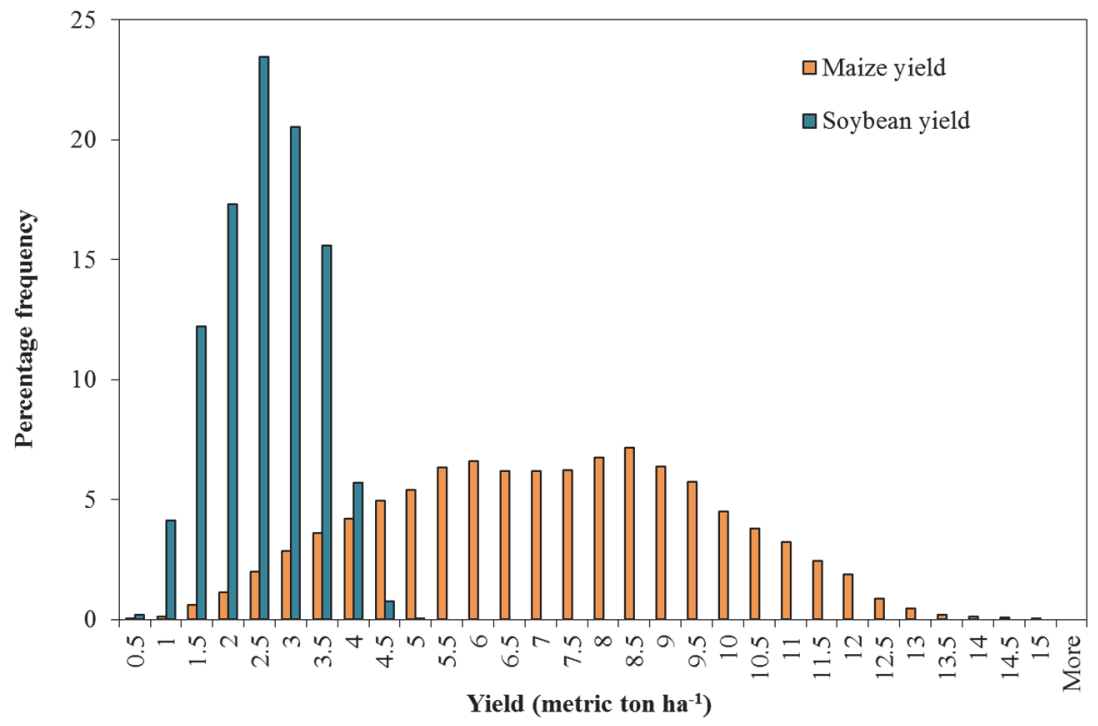

Figure 5. Frequency histograms of observed grain yields for maize and soybean from 1982 to 2013 across the study area. 
yield to the annual or growing season precipitation received in that county in that year. Long-term average magnitudes were calculated for each county, and the results are reported using maps to analyze the spatial distribution across the Great Plains. The annual (Jan. 1 to Dec. 31) precipitation has considerable impact on growing season crop growth and yield due to its role in recharging the soil profile for spring germination and crop water uptake during crop establishment and development. The regional average magnitude of maize ANNPUE was $1.09 \mathrm{~kg} \mathrm{~m}^{-3}$, which was averaged over 680 counties for which long-term datasets were available. The long-term average maize ANNPUE across the region varied from a minimum of $0.12 \mathrm{~kg} \mathrm{~m}^{-3}$ in Galveston County, Texas, to a maximum of $4.82 \mathrm{~kg} \mathrm{~m}^{-3}$ in Hudspeth County, Texas. The SD for maize ANNPUE across the region was $0.59 \mathrm{~kg} \mathrm{~m}^{-3}$. High maize ANNPUE was observed in the western half of the region (fig. 6).

Statewide averaged maize ANNPUE values were also computed from county-level ANNPUE data and analyzed, and the magnitudes of the statewide maize ANNPUE and other descriptive statistics are shown in table 3. On a statewide average basis, Colorado had the highest maize ANNPUE, followed by Wyoming, Nebraska, Kansas, Iowa, North Dakota, Texas, South Dakota, and Oklahoma. The maximum and minimum SD values were observed in Wyoming and Kansas, respectively. The highest CV was observed in Wyoming, while the lowest was in Kansas. The GRSPUE had similar trends as annual PUE. The regional average maize GRSPUE was $1.90 \mathrm{~kg} \mathrm{~m}^{-3}$, which was averaged over 680 counties for which long-term datasets were available. The long-term average maize GRSPUE across the region varied from $0.18 \mathrm{~kg} \mathrm{~m}^{-3}$ in Galveston County, Texas, to $8.25 \mathrm{~kg} \mathrm{~m}^{-3}$ in El Paso County, Texas. The SD observed in maize GRSPUE across the region was $1.01 \mathrm{~kg} \mathrm{~m}^{-3}$. The

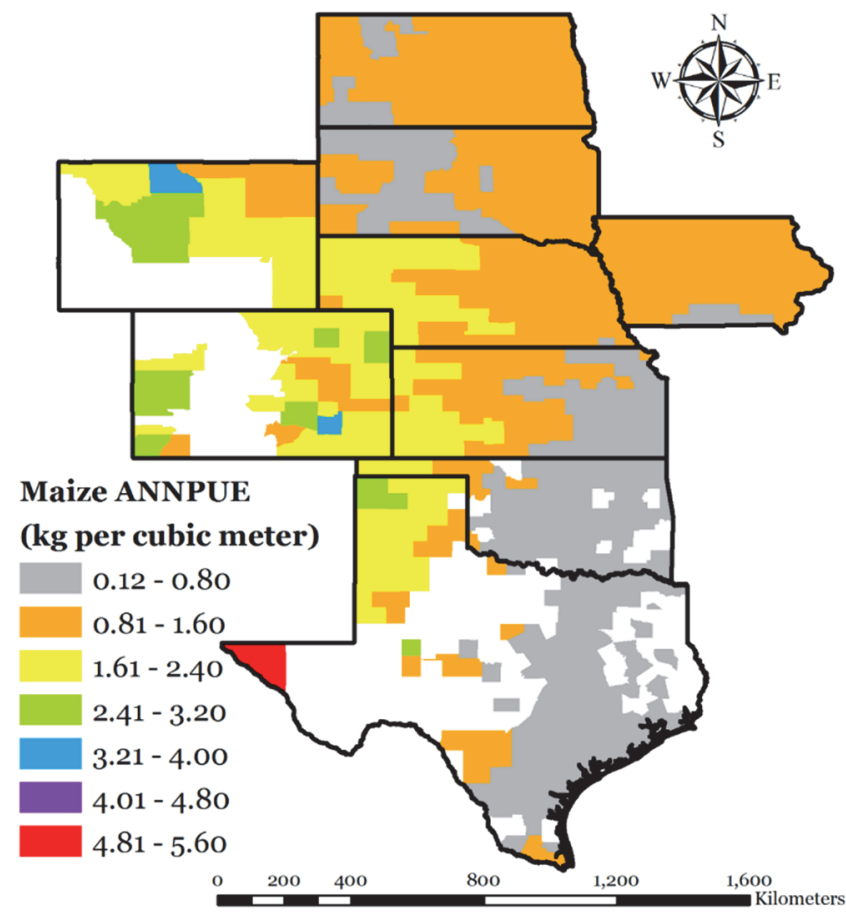

Figure 6. Long-term (1982-2013) average maize annual precipitation use efficiency (ANNPUE) on a county basis $\left(\mathrm{kg} \mathrm{m}^{-3}\right)$.
Table 3. Descriptive statistics of statewide average maize and soybean annual precipitation use efficiency ANNPUE $\left(\mathrm{kg} \mathrm{m}^{-3}\right)$.

\begin{tabular}{lccccc}
\hline Crop and State & Mean & Max. & Min. & SD & CV \\
\hline Maize & & & & & \\
Colorado & 2.120 & 3.550 & 1.599 & 0.403 & 0.190 \\
Iowa & 1.012 & 1.359 & 0.400 & 0.237 & 0.234 \\
Kansas & 1.060 & 1.393 & 0.670 & 0.135 & 0.128 \\
N. Dakota & 0.977 & 1.650 & 0.378 & 0.255 & 0.261 \\
Nebraska & 1.376 & 2.391 & 0.732 & 0.311 & 0.226 \\
Oklahoma & 0.626 & 0.994 & 0.395 & 0.136 & 0.218 \\
S. Dakota & 0.961 & 1.402 & 0.521 & 0.215 & 0.224 \\
Texas & 0.965 & 1.408 & 0.602 & 0.204 & 0.211 \\
Wyoming & 1.982 & 4.448 & 1.338 & 0.682 & 0.344 \\
\hline Soybean & & & & & \\
Iowa & 0.338 & 0.462 & 0.174 & 0.071 & 0.208 \\
Kansas & 0.326 & 0.422 & 0.239 & 0.044 & 0.135 \\
N. Dakota & 0.320 & 0.559 & 0.160 & 0.079 & 0.247 \\
Nebraska & 0.453 & 0.775 & 0.261 & 0.107 & 0.235 \\
Oklahoma & 0.176 & 0.267 & 0.109 & 0.037 & 0.208 \\
S. Dakota & 0.331 & 0.456 & 0.198 & 0.068 & 0.205 \\
Texas & 0.278 & 0.401 & 0.178 & 0.054 & 0.194 \\
\hline
\end{tabular}

highest maize GRSPUE were observed in the western half of the region, similar to ANNPUE (fig. 7). On a statewide average basis, Colorado had the highest maize GRSPUE, followed by Wyoming, Nebraska, Texas, Kansas, Iowa, South Dakota, North Dakota, and Oklahoma. The magnitudes of the statewide maize GRSPUE and other descriptive statistics are shown in table 4 . The maximum and minimum SD values were observed in Wyoming and Oklahoma, respectively. The highest CV was observed in Wyoming, while the lowest was observed in Colorado and Kansas. Irmak (2015a, 2015b) measured ANNPUE and GRSPUE of maize under different irrigation regimes (including rainfed maize) at Clay Center, Nebraska, for the period 2005-2010 and reported that the average ANNPUE and GRSPUE across treatments were 1.82 and $3.04 \mathrm{~kg} \mathrm{~m}^{-3}$, respectively. Those measured values are very similar to our findings.

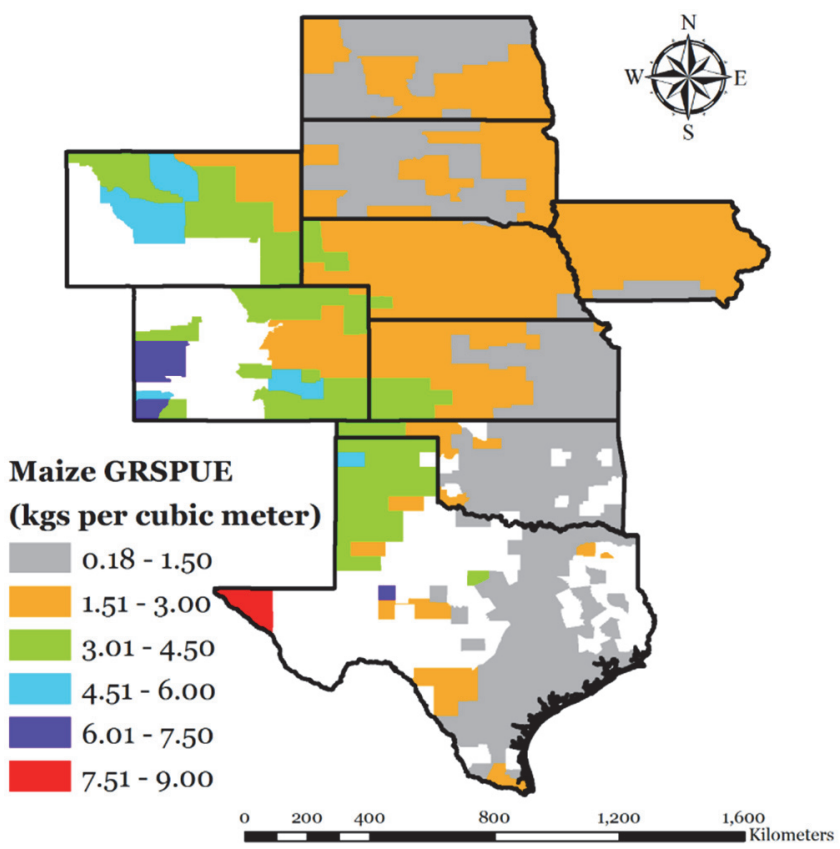

Figure 7. Long-term (1982-2013) average maize growing season precipitation use efficiency (GRSPUE) on a county basis $\left(\mathrm{kg} \mathrm{m}^{-3}\right)$. 
Table 4. Descriptive statistics of statewide average maize and soybean growing season precipitation use efficiency (GRSPUE) $\left(\mathrm{kg} \mathrm{m}^{-3}\right)$.

\begin{tabular}{lccccc}
\hline Crop and State & Mean & Max. & Min. & SD & CV \\
\hline Maize & & & & & \\
Colorado & 3.785 & 6.148 & 2.472 & 0.778 & 0.206 \\
Iowa & 1.715 & 2.737 & 0.537 & 0.439 & 0.256 \\
Kansas & 1.775 & 2.629 & 0.972 & 0.366 & 0.206 \\
N. Dakota & 1.488 & 2.916 & 0.475 & 0.429 & 0.288 \\
Nebraska & 2.193 & 4.939 & 1.024 & 0.658 & 0.300 \\
Oklahoma & 1.256 & 2.138 & 0.757 & 0.344 & 0.274 \\
S. Dakota & 1.535 & 2.515 & 0.729 & 0.414 & 0.270 \\
Texas & 1.925 & 3.756 & 1.158 & 0.496 & 0.258 \\
Wyoming & 3.519 & 7.862 & 2.167 & 1.415 & 0.402 \\
\hline Soybean & & & & & \\
Iowa & 0.574 & 0.994 & 0.233 & 0.137 & 0.238 \\
Kansas & 0.528 & 0.772 & 0.343 & 0.100 & 0.189 \\
N. Dakota & 0.487 & 1.005 & 0.201 & 0.136 & 0.280 \\
Nebraska & 0.707 & 1.593 & 0.386 & 0.217 & 0.307 \\
Oklahoma & 0.335 & 0.473 & 0.208 & 0.074 & 0.221 \\
S. Dakota & 0.551 & 0.845 & 0.269 & 0.134 & 0.244 \\
Texas & 0.503 & 0.788 & 0.325 & 0.113 & 0.226 \\
\hline
\end{tabular}

\section{Soybean PUE}

The regional average magnitude of soybean ANNPUE was $0.32 \mathrm{~kg} \mathrm{~m}^{-3}$, which was averaged over 562 counties for which long-term datasets were available. The long-term average soybean ANNPUE across the region varied from $0.06 \mathrm{~kg} \mathrm{~m}^{-3}$ in Orange County, Texas, to $0.70 \mathrm{~kg} \mathrm{~m}^{-3}$ in Sioux County, Nebraska. The SD observed in soybean ANNPUE across the region was $0.13 \mathrm{~kg} \mathrm{~m}^{-3}$. The high soybean ANNPUE values were observed over the western parts of Nebraska, Kansas, Oklahoma, and Texas (fig. 8). Soybean ANNPUE and GRSPPUE values were not reported for Wyoming and Colorado due to the absence of soybean yield data. Statewide averaged soybean ANNPUE values were computed from county-level ANNPUE data and analyzed to compare statewide ANNPUE. On a statewide average basis, Nebraska had the highest soybean ANNPUE, followed by Iowa, South Dakota, Kansas, North Dakota, Texas, and Ok-

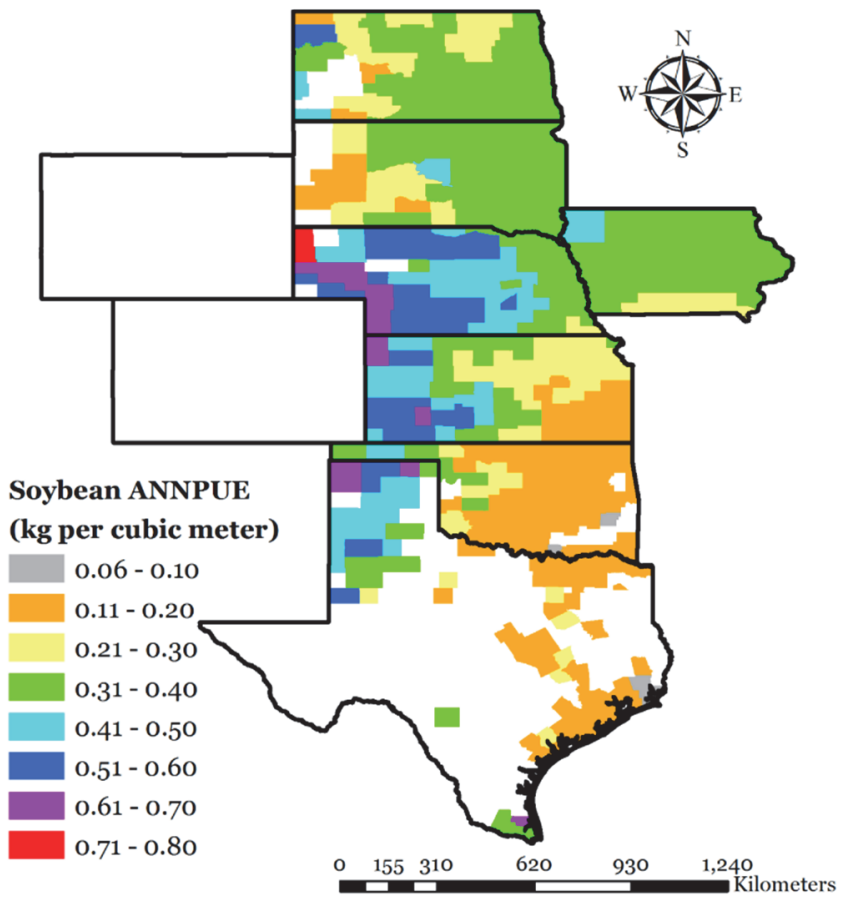

Figure 8. Long-term (1982-2013) average soybean annual precipitation use efficiency (ANNPUE) on a county basis $\left(\mathrm{kg} \mathrm{m}^{-3}\right)$. lahoma. The magnitudes of the statewide soybean ANNPUE and other descriptive statistics are shown in table 3 . The maximum and minimum SD values were observed in $\mathrm{Ne}$ braska and Oklahoma, respectively. The highest CV was observed in North Dakota, while the lowest was observed in Kansas. The GRSPUE had similar trends as ANNPUE. The regional average soybean GRSPUE was $0.55 \mathrm{~kg} \mathrm{~m}^{-3}$, which was averaged over 562 counties. Long-term average soybean GRSPUE across the region varied from $0.14 \mathrm{~kg} \mathrm{~m}^{-3}$ in Hardin County, Texas, to $1.47 \mathrm{~kg} \mathrm{~m}^{-3}$ in Willacy County, Texas. The SD of soybean GRSPUE across the region was $0.20 \mathrm{~kg}$ $\mathrm{m}^{-3}$. The high soybean GRSPUE values were observed in the western parts of Nebraska, Kansas, Oklahoma, and Texas, similar to ANNPUE (fig. 9). On a statewide average basis, Nebraska had the highest soybean GRSPUE, followed by Iowa, South Dakota, Kansas, Texas, North Dakota, and Oklahoma. The statewide soybean GRSPUE and other descriptive statistics are shown in table 4.

The geographical (spatial) trends in both ANNPUE and GRSPUE (maize or soybean) are a function of the spatial trends in observed crop yield (maize or soybean) and precipitation (annual or growing season). Precipitation amounts have a longitudinal trend across the region and increase toward the east. Kukal and Irmak (2016a) reported that the long-term average (1968-2013) annual precipitation ranges from $215 \mathrm{~mm}$ in the west to $1450 \mathrm{~mm}$ in the southeast. Similarly, long-term average (1968-2013) growing season (1 May to 30 Sept.) precipitation varies from $120 \mathrm{~mm}$ in the west to $700 \mathrm{~mm}$ in the southeast. However, crop yield does not follow a particular longitudinal or latitudinal trend, as crop yield is a function of highly variable management practices, irrigation, soil conditions, growing season length, crop genetics, and other factors that vary on very fine scales. In particular, irrigation has a substantial role in achieving greater crop yields. For example, Nebraska, Kansas, and

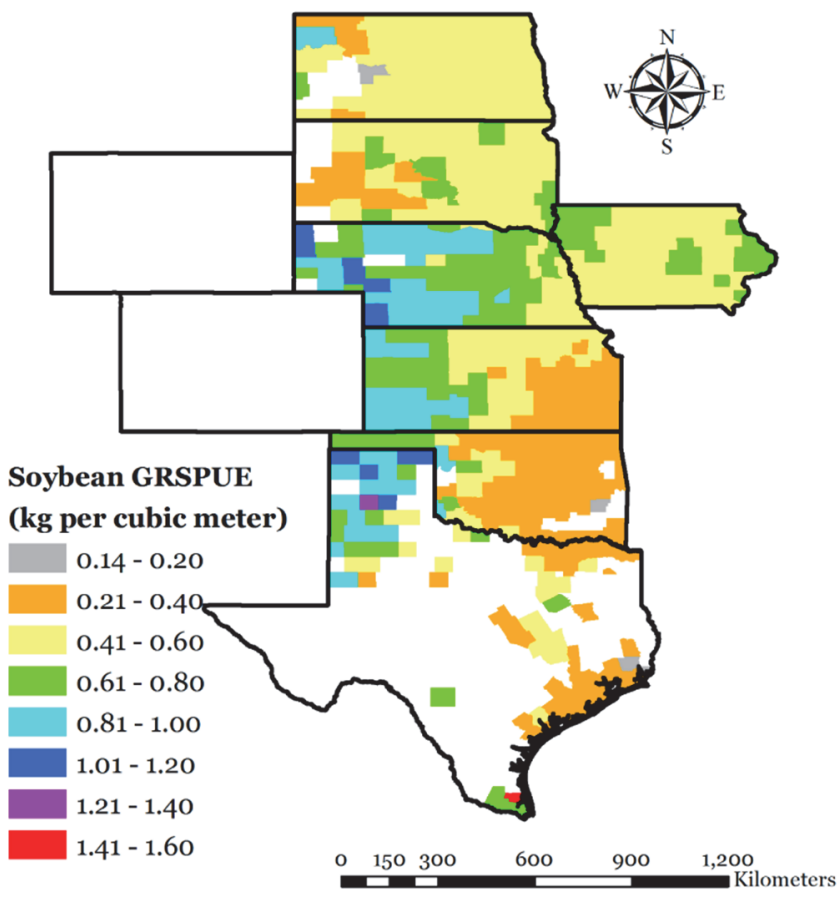

Figure 9. Long-term (1982-2013) averaged soybean growing season precipitation use efficiency (GRSPUE) on county basis $\left(\mathrm{kg} \mathrm{m}^{-3}\right)$. 
Texas are states with a greater proportion of irrigated fields and show relatively greater crop yields; hence, irrigation is likely to affect their PUE metrics. PUE, which is essentially the ratio of crop yield to precipitation, is characterized by the absence of any particular spatial trend, although a slight longitudinal trend exists because of the precipitation gradient in regions that show comparable crop yields. This is one of the reasons behind the generally decreasing trend from west to east in all the PUE metrics, which is due to the increase in precipitation amounts from west to east. Hence, spatial trends in PUE metrics are governed by the spatial trends in crop yield and precipitation, which vary substantially.

The proportion of counties that showed increasing trends in maize ANNPUE was $88 \%$, while $85 \%$ of the counties showed increasing trends in maize GRSPUE. The remainder of the counties showed decreasing trends. The increase or decrease in these temporal trends for each county in the study area and their significance are shown in figure 10. For maize ANNPUE, counties in northwest, north central, central, and west central Kansas and in the Platte drainage basin, Kansas drainage basin, and Arkansas drainage basin in Colorado showed significant decreasing trends. Among other decreasing trends in the region were some counties in southwest and central South Dakota, Nebraska, Oklahoma, and Texas. The region showed similar trends for maize GRSPUE and ANNPUE. Increasing trends for maize ANNPUE ranged from 0.00003 to $0.0751 \mathrm{~kg} \mathrm{~m}^{-3}$ year ${ }^{-1}$ with a regional average of $0.0174 \mathrm{~kg} \mathrm{~m}^{-3}$ year-1 $^{-1}$. Decreasing trends ranged from 0.0001 to $0.05 \mathrm{~kg} \mathrm{~m}^{-3}$ year-1 with a regional average of $0.0094 \mathrm{~kg} \mathrm{~m}^{-3}$ year ${ }^{-1}$. Increasing trends for maize GRSPUE ranged from 0.0001 to $0.2480 \mathrm{~kg} \mathrm{~m}^{-3}$ year ${ }^{-1}$ with a regional average of $0.0316 \mathrm{~kg} \mathrm{~m}^{-3} \mathrm{year}^{-1}$. Likewise, decreasing trends ranged from 0.00004 to $0.1084 \mathrm{~kg} \mathrm{~m}^{-3}$ year-1 with a regional average of $0.0176 \mathrm{~kg} \mathrm{~m}^{-3} \mathrm{year}^{-1}$. The regional increasing trends in maize ANNPUE were $82 \%$ greater than those of maize GRSPUE.
The proportion of counties that showed increasing trends in soybean ANNPUE was $91 \%$, while $87 \%$ of the counties showed increasing trends in soybean GRSPUE (fig. 11). For soybean ANNPUE, counties in northwest, north central, central, and west central Kansas and eastern Texas showed significant decreasing trends. Among other decreasing trends in the region were some counties in South Dakota, Nebraska, Oklahoma, and Texas. The region showed similar trends for soybean GRSPUE and ANNPUE. Increasing trends for soybean ANNPUE ranged from 0.00003 to 0.0303 $\mathrm{kg} \mathrm{m}^{-3}$ year-1 with a regional average of $0.0048 \mathrm{~kg} \mathrm{~m}^{-3}$ year ${ }^{-1}$. Decreasing trends ranged from 0.0001 to $0.0112 \mathrm{~kg}$ $\mathrm{m}^{-3}$ year $^{-1}$ with a regional average of $0.0020 \mathrm{~kg} \mathrm{~m}^{-3}$ year $^{-1}$. Increasing trends for soybean GRSPUE ranged from 0.0001 to $0.0480 \mathrm{~kg} \mathrm{~m}^{-3}$ year $^{-1}$ with a regional average of $0.0081 \mathrm{~kg}$ $\mathrm{m}^{-3}$ year $^{-1}$. Decreasing trends ranged from 0.0001 to 0.0117 $\mathrm{kg} \mathrm{m}^{-3}$ year-1 with a regional average of $0.0032 \mathrm{~kg} \mathrm{~m}^{-3}$ year $^{-1}$. The increasing trend in soybean ANNPUE was $69 \%$ greater than that of soybean GRSPUE.

Crop PUE should be treated as a measure to denote crop yield in a particular county in relation to the precipitation it receives during a particular period. However, it should not be used to represent or indicate the efficiency of a particular region to store precipitation to contribute to crop water needs. This would require more information on soil properties related to water storage (such as water holding capacity) at various depths and information on soil-water extraction patterns by various crops, which is very limited, especially at large scales. Moreover, crop PUE does not account for irrigation water application to supplement precipitation. Nevertheless, it indicates the relative ratio of crop yield to precipitation, which is valuable information, especially for counties with dominantly rainfed fields, such as in Iowa and southeastern Nebraska. a)

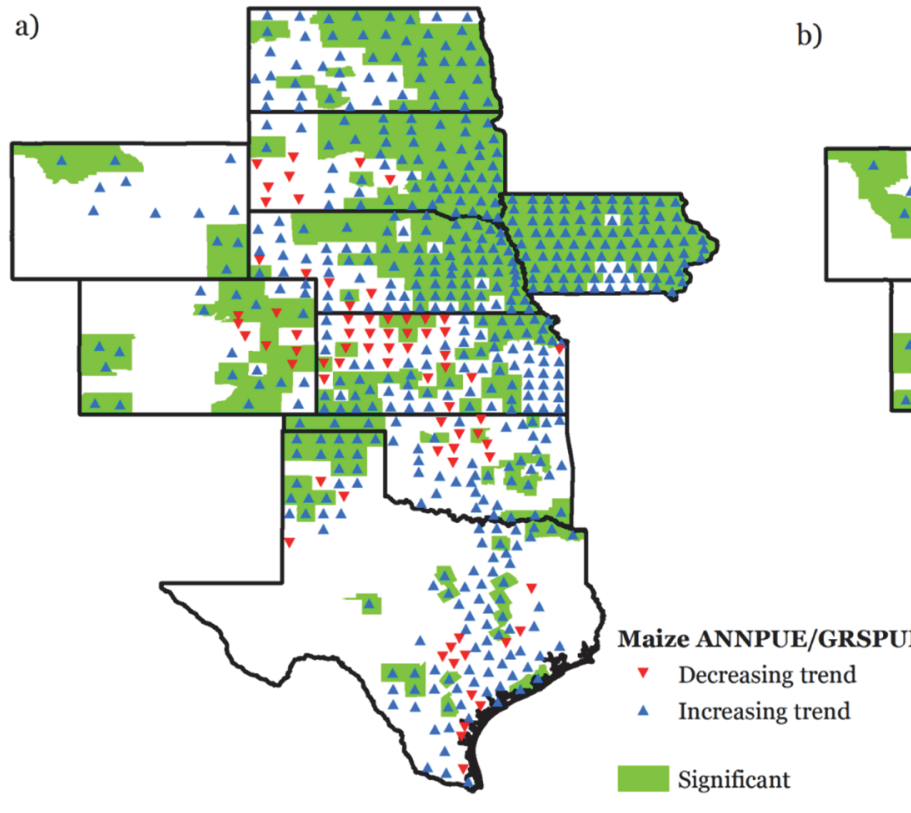

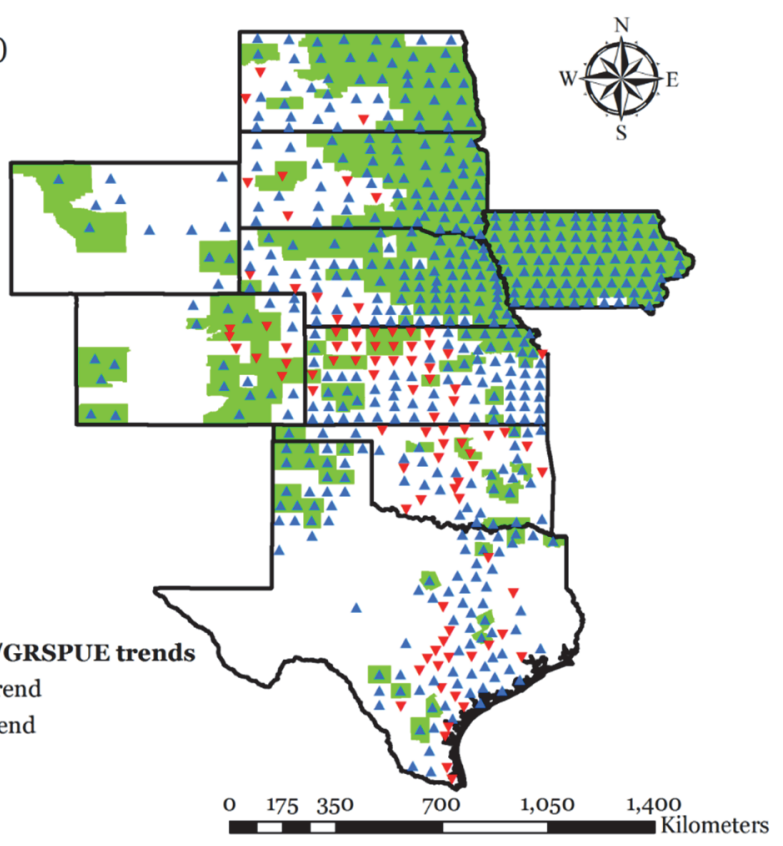

Figure 10. Temporal trends in (a) maize annual precipitation use efficiency (ANNPUE) and (b) maize growing season precipitation use efficiency (GRSPUE) $\left(\mathrm{kg} \mathrm{m}^{-3}\right)$ during the period 1982-2013 for the study region counties. 
a)

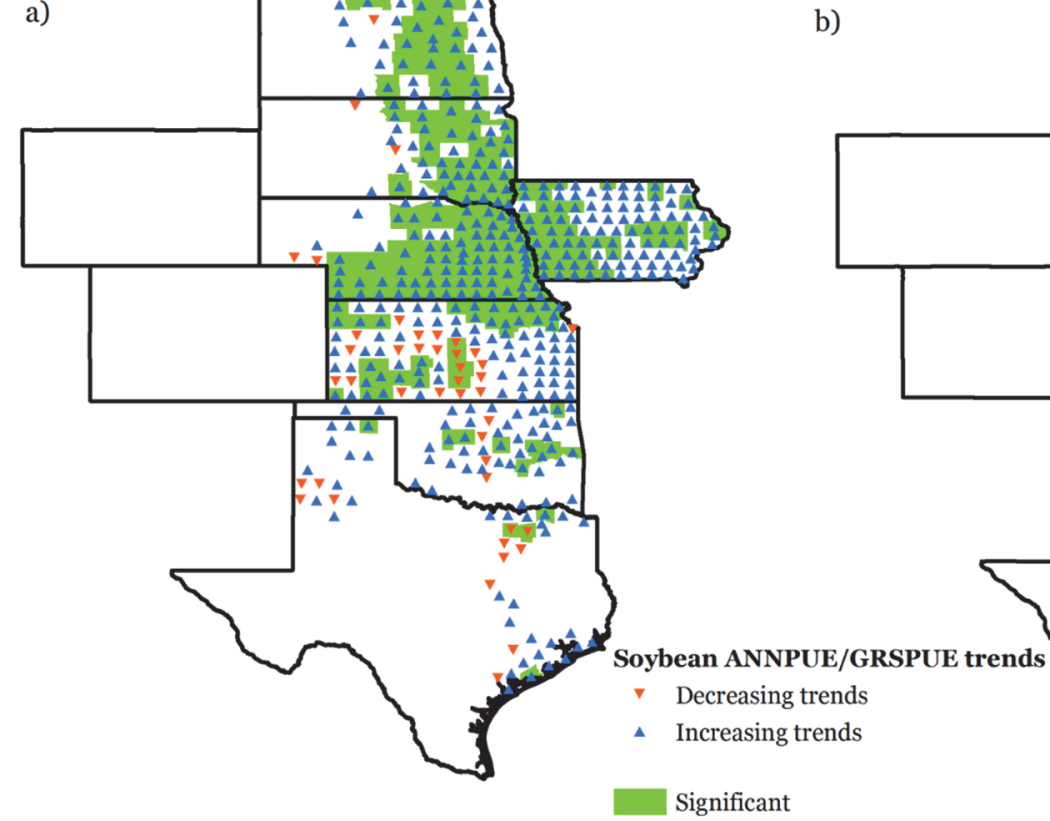

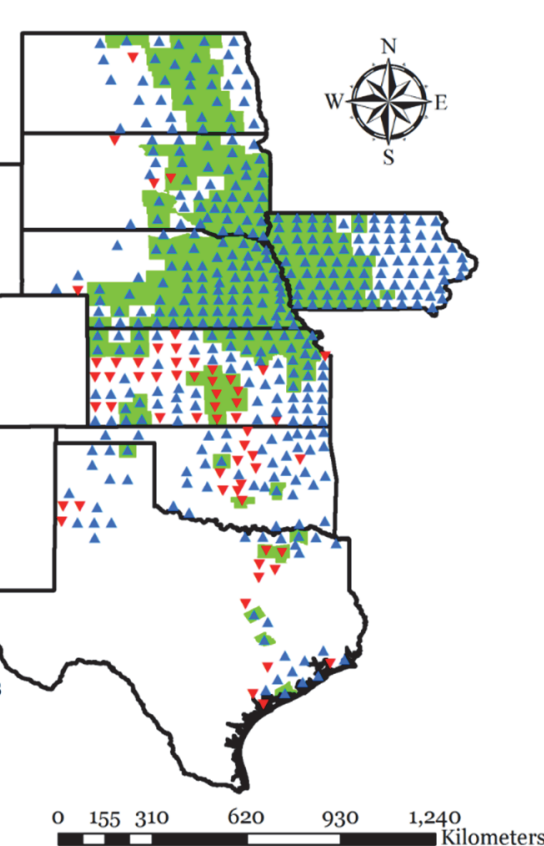

Figure 11. Temporal trends in (a) soybean annual precipitation use efficiency (ANNPUE) and (b) soybean growing season precipitation use efficiency (GRSPUE) $\left(\mathrm{kg} \mathrm{m}^{-3}\right)$ during the period 1982-2013 for the study region counties.

\section{Histograms of PUE Frequency Distributions}

To assess the changes in ANNPUE and GRSPUE for maize and soybean in a quantitative way, histograms of frequency distributions were developed (figs. 12 and 13, respectively). These histograms show the range and distribution of ANNPUE and GRSPUE across the Great Plains. A total of 17,793 observation data points for maize and 13,288 observation data points for soybean were used to develop the frequency distribution histograms. Maize ANNPUE ranged from 0.06 to $7.46 \mathrm{~kg} \mathrm{~m}^{-3}$ with a peak frequency range of 0.5 to $0.75 \mathrm{~kg} \mathrm{~m}^{-3}$. Maize GRSPUE ranged from 0.12 to $15.12 \mathrm{~kg}$ $\mathrm{m}^{-3}$ with a peak frequency range of 1.25 to $1.5 \mathrm{~kg} \mathrm{~m}^{-3}$. Soy- bean ANNPUE ranged from 0.04 to $1.79 \mathrm{~kg} \mathrm{~m}^{-3}$ with a peak frequency range of 0.3 to $0.35 \mathrm{~kg} \mathrm{~m}^{-3}$. Soybean GRSPUE ranged from 0.07 to $4.08 \mathrm{~kg} \mathrm{~m}^{-3}$ with a peak frequency range of 0.5 to $0.55 \mathrm{~kg} \mathrm{~m}^{-3}$. To further investigate the variation in crop ANNPUE and GRSPUE during 1982-2013, the skewness statistic was calculated for each year (table 2) to quantify the variation in frequency distribution over the study period. For most of the years, the skewness has positive values, which implies that the histogram distribution is more skewed toward lower ANNPUE and GRSPUE for both crops during the study period.

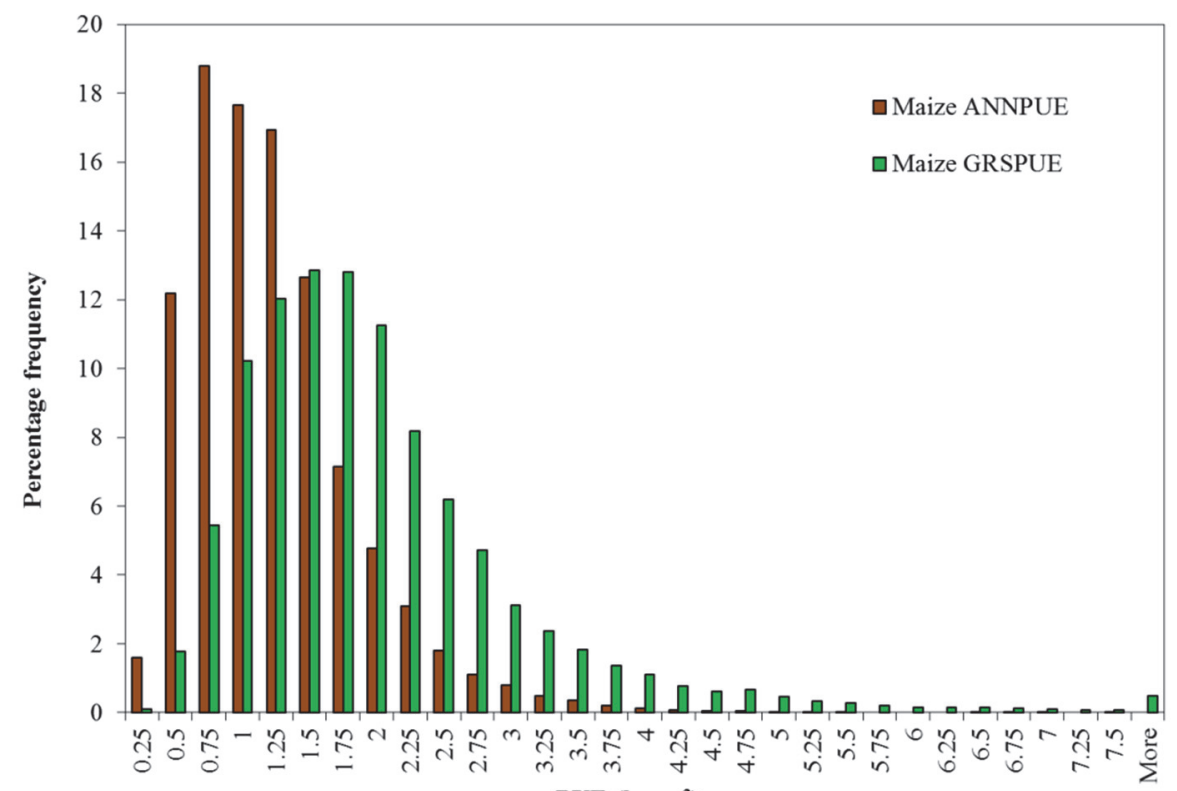

PUE $\left(\mathrm{kg} \mathrm{m}^{-3}\right)$

Figure 12. Frequency histograms of county average maize annual precipitation use efficiency (ANNPUE) and growing season precipitation use efficiency (GRSPUE) from 1982 to 2013 across the study area. 


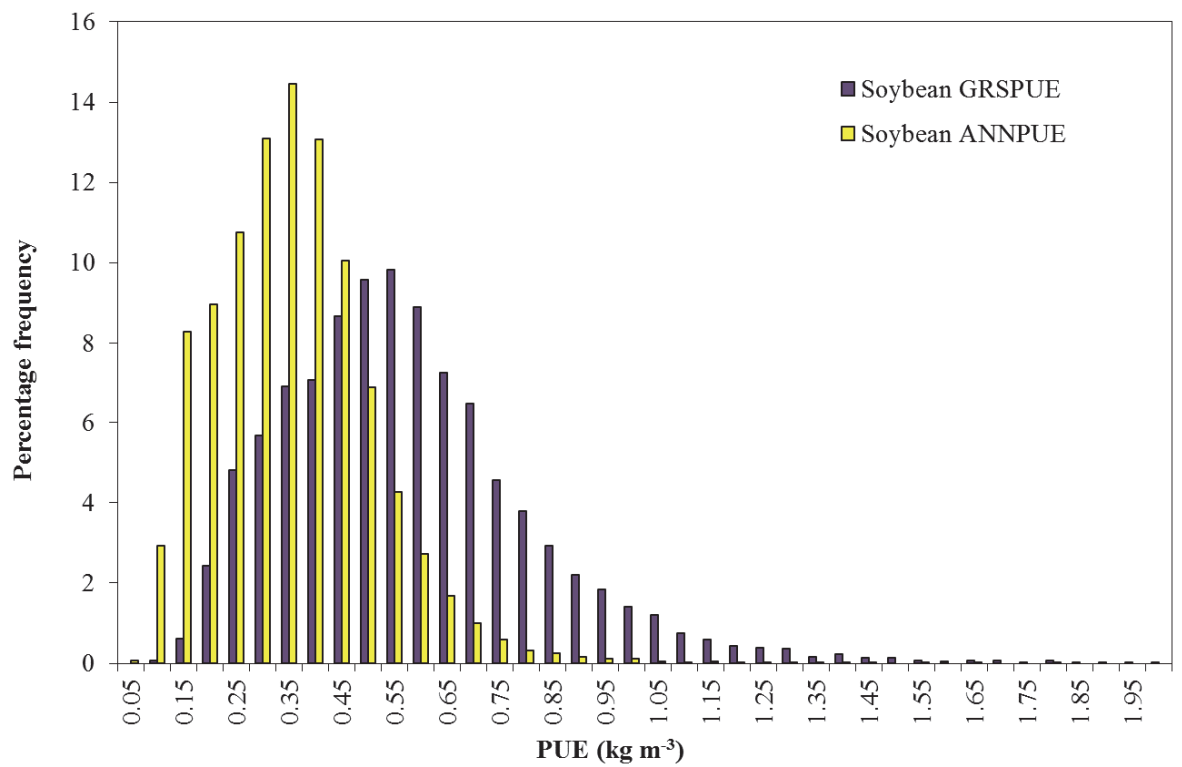

Figure 13. Frequency histograms of county average soybean annual precipitation use efficiency (ANNPUE) and growing season precipitation use efficiency (GRSPUE) from 1982 to 2013 across the study area.

\section{SPATIAL AND TEMPORAL TRENDS IN CWP}

The regional average maize CWP was $1.08 \mathrm{~kg} \mathrm{~m}^{-3}$, which was averaged over 604 counties for which long-term datasets of both maize yield and ET were available. The long-term average maize CWP across the region varied from $0.30 \mathrm{~kg}$ $\mathrm{m}^{-3}$ in Lee County, Texas, to $2.97 \mathrm{~kg} \mathrm{~m}^{-3}$ in Park County, Wyoming. The regional average SD for maize CWP was $0.39 \mathrm{~kg} \mathrm{~m}^{-3}$. High maize CWP values were observed in central Nebraska, western Kansas, and Iowa (fig. 14). The magnitudes of the statewide maize CWP and other descriptive

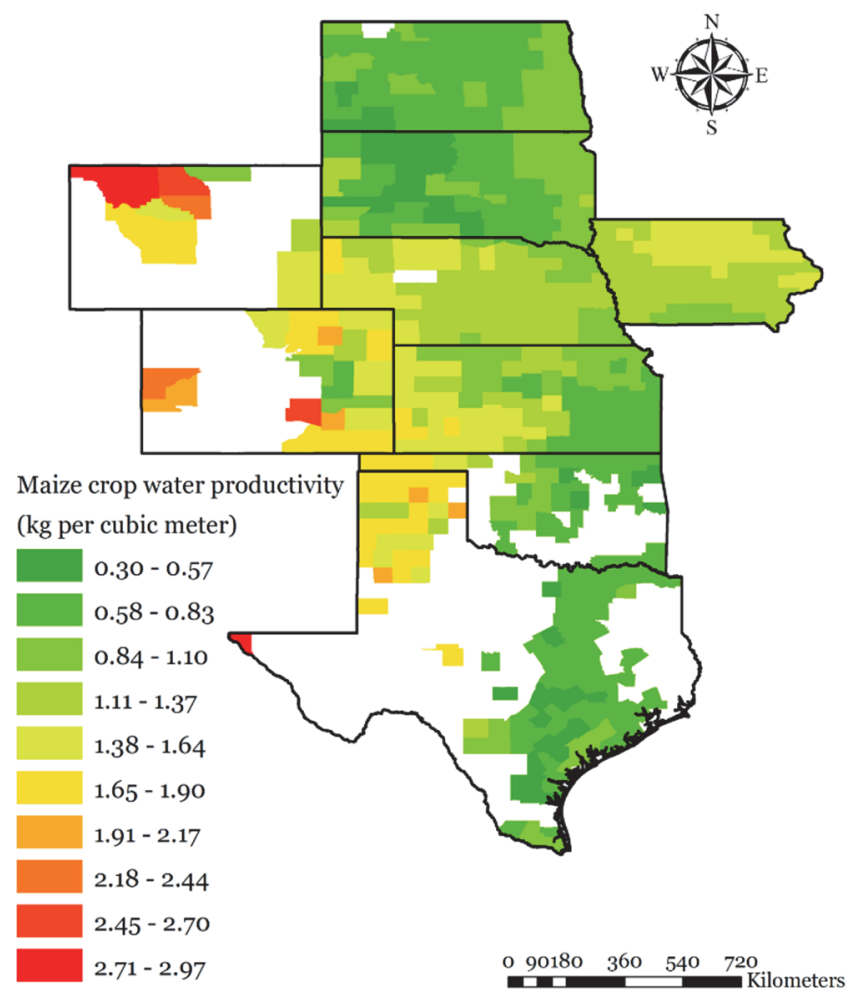

Figure 14. Long-term (1982-2013) average maize crop water productivity (CWP) $\left(\mathrm{kg} \mathrm{m}^{-3}\right)$ on a county basis. statistics are shown in table 5. Statewide averaged maize CWP values were also computed from county-level CWP data and analyzed to compare statewide CWP. On a statewide average basis, Wyoming had the highest maize CWP, followed by Colorado, Iowa, Nebraska, Kansas, Texas, Oklahoma, South Dakota, and North Dakota. The maximum and minimum SD values were observed in Wyoming and Texas, respectively. The highest magnitude of $\mathrm{CV}$ was observed in North Dakota, while the lowest was observed in Colorado. Numerous researchers have reported experimentally measured maize CWP values in the semi-arid central and southern High Plains. Tolk et al. (1999) reported that maize CWP at Bushland, Texas, ranged from 1.26 to $1.54 \mathrm{~kg} \mathrm{~m}^{-3}$, depending on tillage practices, irrigation, and soil type. At the same location, other researchers reported maize CWP ranges of 1.12 to $1.39 \mathrm{~kg} \mathrm{~m}^{-3}$ (Evett et al., 1996), 0.89 to $1.55 \mathrm{~kg} \mathrm{~m}^{-3}$ (Howell et al., 1995), 1.47 to $1.74 \mathrm{~kg}$ $\mathrm{m}^{-3}$ (Howell et al., 1996), and 1.13 to $1.68 \mathrm{~kg} \mathrm{~m}^{-3}$ (Yazar et al., 1999). Norwood et al. (2000) found that the CWP of water-limited and dryland maize ranged from 0.83 to $1.61 \mathrm{~kg}$

Table 5. Descriptive statistics of statewide averaged maize and soybean crop water use productivity (CWP) $\left(\mathrm{kg} \mathrm{m}^{-3}\right)$.

\begin{tabular}{lccccc}
\hline Crop and State & Mean & Max. & Min. & SD & CV \\
\hline Maize & & & & & \\
$\quad$ Colorado & 1.668 & 1.946 & 1.414 & 0.150 & 0.090 \\
Iowa & 1.290 & 1.685 & 0.655 & 0.246 & 0.190 \\
Kansas & 1.102 & 1.373 & 0.818 & 0.141 & 0.128 \\
N. Dakota & 0.778 & 1.138 & 0.391 & 0.200 & 0.258 \\
Nebraska & 1.247 & 1.576 & 0.941 & 0.147 & 0.118 \\
Oklahoma & 0.846 & 1.129 & 0.475 & 0.152 & 0.180 \\
S. Dakota & 0.811 & 1.299 & 0.493 & 0.197 & 0.243 \\
Texas & 0.955 & 1.136 & 0.700 & 0.112 & 0.117 \\
Wyoming & 1.951 & 2.549 & 1.460 & 0.292 & 0.149 \\
\hline Soybean & & & & & \\
Iowa & 0.497 & 0.586 & 0.307 & 0.070 & 0.142 \\
Kansas & 0.400 & 0.522 & 0.269 & 0.064 & 0.161 \\
N. Dakota & 0.298 & 0.415 & 0.161 & 0.073 & 0.246 \\
Nebraska & 0.474 & 0.602 & 0.326 & 0.069 & 0.146 \\
Oklahoma & 0.256 & 0.316 & 0.137 & 0.048 & 0.188 \\
S. Dakota & 0.336 & 0.485 & 0.234 & 0.062 & 0.184 \\
Texas & 0.320 & 0.408 & 0.219 & 0.052 & 0.163 \\
\hline
\end{tabular}


$\mathrm{m}^{-3}$. Irmak (2015a, 2015b) measured long-term center-pivot irrigated maize CWP values at Clay Center, Nebraska, for the period 2005-2010 under different irrigation regimes. He found that, on average, CWP ranged from $1.73 \mathrm{~kg} \mathrm{~m}^{-3}$ for rainfed maize to $2.34 \mathrm{~kg} \mathrm{~m}^{-3}$ for fully irrigated maize. Payero et al. (2009) reported maize CWP values ranging from 1.80 to $2.05 \mathrm{~kg} \mathrm{~m}^{-3}$ in 2005 and from 1.50 to $1.92 \mathrm{~kg} \mathrm{~m}^{-3}$ in 2006 with various irrigation treatments at North Platte, Nebraska. Irmak et al. (2012a) observed similar measured CWP values for eight large-scale production fields across central, south central, and eastern Nebraska, with maize CWP ranging from 2.1 to $4 \mathrm{~kg} \mathrm{~m}^{-3}$ under proper irrigation and crop management practices.

It is possible that some of the county-based CWP values in our analyses may be lower than the measured CWP values reported in the literature. It should be noted that the crop yield data and crop ET data used in our study were countyaveraged values. In addition, our analyses represent an average of irrigated and rainfed conditions because the datasets were averaged across management practices and hence did not distinguish between irrigated and non-irrigated regimes. In some cases, as discussed by Kukal et al. (2017), crop ET magnitudes may be overestimated owing to the use of twostep approach, resulting in lower CWP values. Furthermore, experimentally measured CWP is expected to be greater than CWP values obtained from large-scale production fields because experimentally measured values are measured in carefully controlled environments that usually result in greater yields with carefully managed water, nutrients, pesticides, soil, and other crop management practices. The results reported in our study are invaluable in terms of analyzing the regional magnitudes and patterns of CWP at large scales that have very different climatic and soil and management conditions. Our results align strongly with other regional-scale CWP studies. For example, Brauman et al. (2013) reported that maize CWP values for the region are around and above $1.7 \mathrm{~kg} \mathrm{~m}^{-3}$.

Similar analyses were carried out for counties that grow soybean. The regional average soybean CWP was $0.40 \mathrm{~kg}$ $\mathrm{m}^{-3}$, which was averaged over 452 counties. The long-term average soybean CWP across the region varied from $0.15 \mathrm{~kg}$ $\mathrm{m}^{-3}$ in Pennington County, South Dakota, to $0.67 \mathrm{~kg} \mathrm{~m}^{-3}$ in Ochiltree County, Texas. The regional average maize CWP was $170 \%$ higher than the soybean CWP. The SD observed in maize CWP across the region was $0.11 \mathrm{~kg} \mathrm{~m}^{-3}$. Some of the highest CWP values were observed in central Nebraska, western Kansas, and Iowa (fig. 15). On a statewide average scale, Iowa had the highest soybean CWP, followed by Nebraska, Kansas, South Dakota, Texas, North Dakota, and Oklahoma. The statewide soybean CWP and other descriptive statistics are shown in table 5. The maximum and minimum SD values were observed in North Dakota and Oklahoma, respectively. The highest CV was observed in North Dakota, while the lowest was observed in Iowa. Payero et al. (2005) measured CWP values for soybean under deficit irrigation and found that the overall mean CWP was 0.49 and $0.58 \mathrm{~kg} \mathrm{~m}^{-3}$ at North Platte, Nebraska, in 2003 and 2004, respectively, and $0.37 \mathrm{~kg} \mathrm{~m}^{-3}$ at Curtis, Nebraska, in 2002. At Clay Center, Nebraska, Irmak et al. (2014) reported that average soybean CWP values for different irrigation regimes

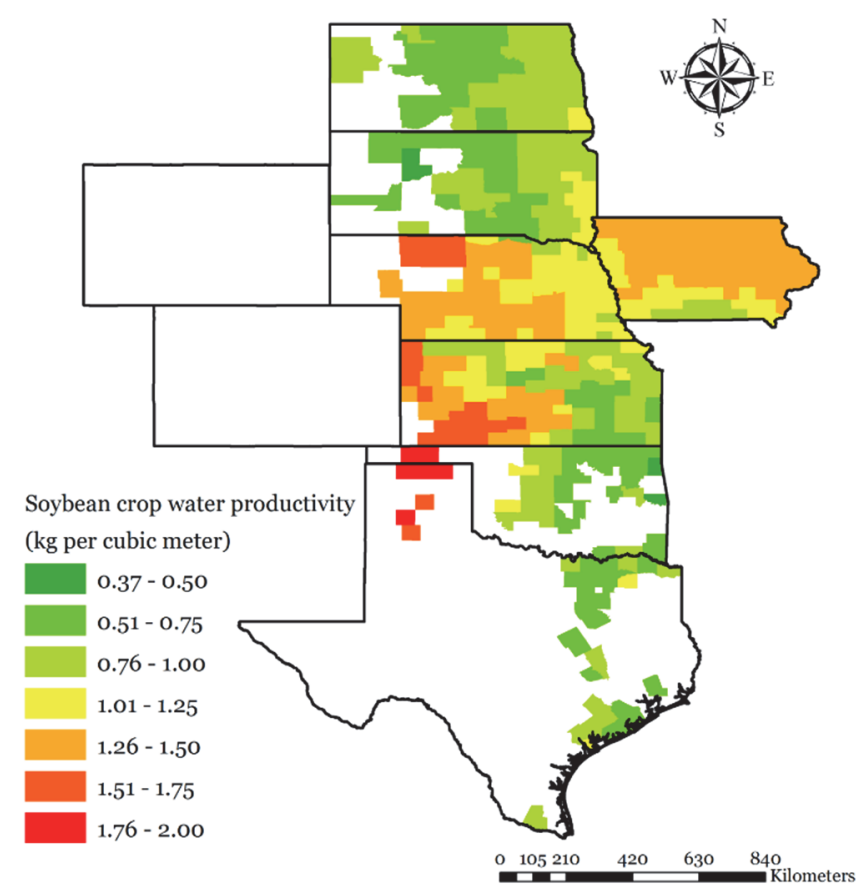

Figure 15. Long-term (1982-2013) average soybean crop water productivity (CWP) $\left(\mathrm{kg} \mathrm{m}^{-3}\right)$ on a county basis.

were between 0.77 and $0.89 \mathrm{~kg} \mathrm{~m}^{-3}$ in 2007 and between 0.85 and $1.02 \mathrm{~kg} \mathrm{~m}^{-3}$ in 2008. Karam et al. (2005) reported soybean CWP to vary between 0.39 and $0.57 \mathrm{~kg} \mathrm{~m}^{-3}$ in Lebanon. Scott et al. (1987) reported that the average CWP of soybean was approximately $0.6 \mathrm{~kg} \mathrm{~m}^{-3}$ in Arkansas. The CWP values obtained were in agreement with experimentally determined values.

The metabolic pathway of photosynthesis (C4 vs. C3) and crop-specific seed composition are the two most important plant factors affecting yield per unit seasonal evapotranspiration. The trade-off between leaf photosynthesis and water loss is inherently higher in C4 crops (Howell, 1990; Niu et al., 2005). This difference is reflected in the higher yield per unit seasonal transpiration of maize compared with their $\mathrm{C} 3$ counterparts, such as soybean.

The proportion of counties that showed increasing trends in maize CWP was $79 \%$, while $86 \%$ of the counties showed increasing trends in soybean CWP. The remainder of the counties showed decreasing trends. These temporal trends for each county in the study area and their significance are shown in figure 16. For maize CWP, the increasing trends are dominant in the region except for some counties that show negative trends. The counties with negative trends are in western North Dakota, western South Dakota, Wyoming, Colorado, as well as northwest, north central, central, west central, and south central Kansas, north central Oklahoma, and the High Plains, south central, and northern Texas. Of all the decreasing trends, only the trends in Colorado and Kansas are significant. In the region, increasing trends for maize CWP ranged from 0.00004 to $0.0732 \mathrm{~kg} \mathrm{~m}^{-3}$ year $^{-1}$ with a regional average of $0.0144 \mathrm{~kg} \mathrm{~m}^{-3}$ year $^{-1}$. Similarly, decreasing trends ranged from 0.00002 to $0.0640 \mathrm{~kg} \mathrm{~m}^{-3}$ year ${ }^{-1}$ with a regional average of $0.01 \mathrm{~kg} \mathrm{~m}^{-3} \mathrm{year}^{-1}$. The increasing and decreasing trends in soybean CWP are located in the same regions as maize CWP, the only difference being 


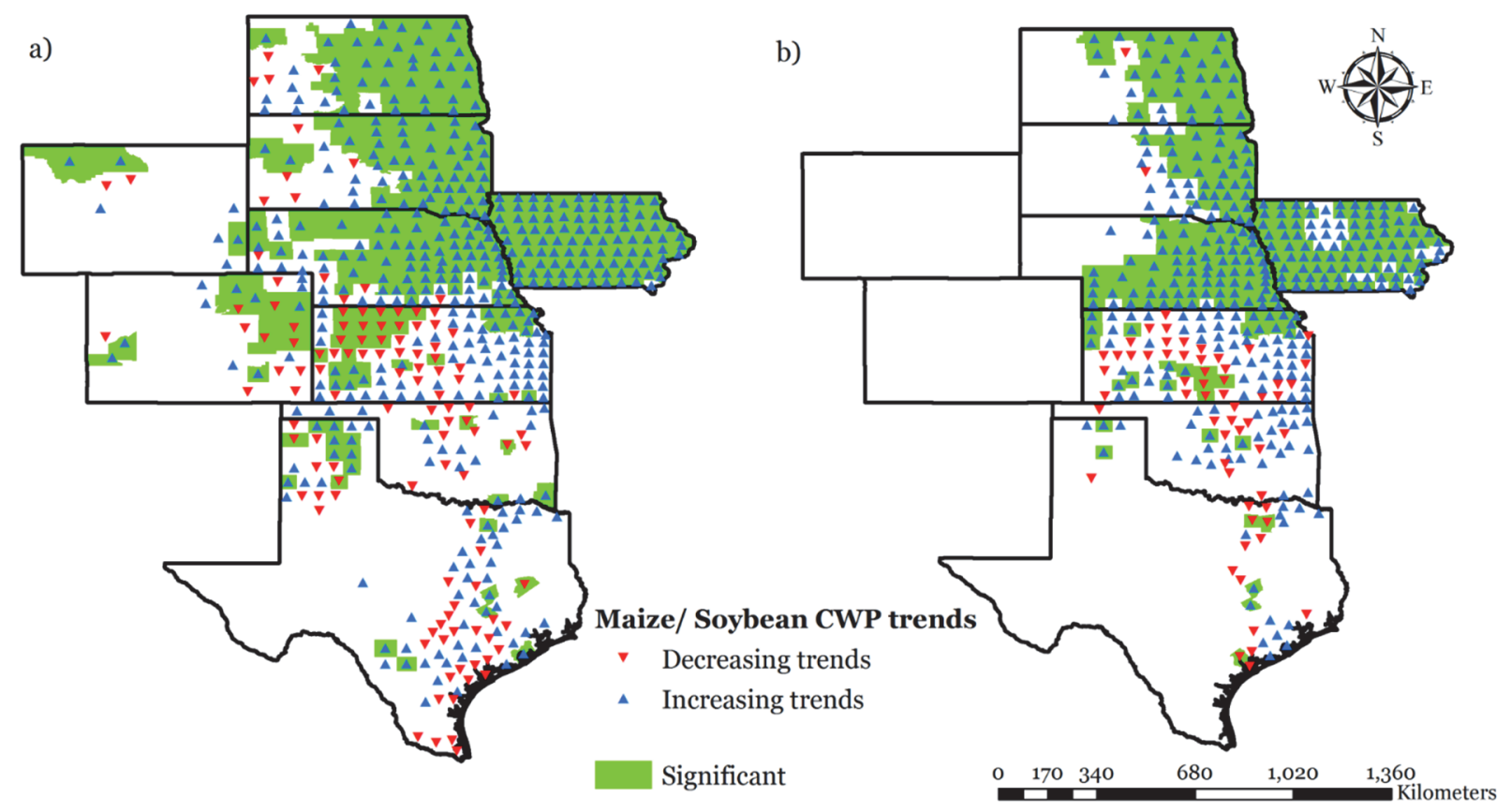

Figure 16. Temporal trends in (a) maize crop water productivity (CWP) and (b) soybean crop water productivity (CWP) (kg $\left.\mathrm{m}^{-3}\right)$ during the period 1982-2013 for the study region counties.

the absence of reported trends in Colorado and Wyoming due to the absence of long-term datasets. The increasing trends for soybean CWP ranged from 0.00001 to $0.0281 \mathrm{~kg}$ $\mathrm{m}^{-3}$ year $^{-1}$ with a regional average of $0.0047 \mathrm{~kg} \mathrm{~m}^{-3}$ year-1. Likewise, the decreasing trends ranged from 0.00003 to $0.0127 \mathrm{~kg} \mathrm{~m}^{-3}$ year $^{-1}$ with a regional average of $0.0031 \mathrm{~kg}$ $\mathrm{m}^{-3}$ year $^{-1}$. Therefore, it was observed that the regional increasing trends for maize CWP were 206\% greater than those for soybean CWP.

Crop water productivity trends in both space and time provide crucial information on the improvements or declines in amount of crop produced by evapotranspiring a given unit of water. The maps showing spatial and temporal trends provide simple representations of intercomparison of CWP and variability in its temporal trends among counties and regions. The region can be assessed for areas with relatively low CWP and for the factors that cause this. Further, if the causes arise from lack of appropriate management practices, inadequate inputs, and other manageable aspects, attempts can be made to improve them, and hence improve CWP, in these regions. Some examples of these regions would be central South Dakota, southeastern Kansas, eastern Oklahoma, and eastern Texas for maize (shown in dark green color in fig. 14) and central North Dakota, South Dakota, eastern Oklahoma, and Texas for soybean (shown in dark green color in fig. 15). However, atmospheric evaporative demand or reference evapotranspiration varies across the region, as quantified and represented by Kukal and Irmak (2016a). A region with higher evaporative demand may also show higher crop water use (crop ET) and hence lower CWP for the same yield level. Hence, the gap in CWP in these regions may not be closed by improving management, and the computed CWP may be a benchmark for the region, which makes inter-region comparison difficult. Some studies, such as Steduto et al. (2009), Hsiao et al. (2009), and Yuan et al.
(2013), used a normalized CWP measure to normalize or correct CWP values to evaporative demand in a particular region, which allowed better comparison across regions and seasons.

In addition, it can be argued that the yield, crop water use, and hence CWP reported in this study are combined estimates for both rainfed (dryland) and irrigated conditions. Crop performance and water use can vary substantially among dryland and irrigated conditions, especially in semiarid regions. County-level crop yield, as stated earlier, is a weighted average of irrigated and rainfed yields and hence correctly represents the county-average magnitude. Moreover, the crop water use estimation methodology involves using satellite-derived NDVI for deducing $K_{\mathrm{c}}$ information. Because the NDVI data reflect whether a field is rainfed (dryland) or irrigated, the $K_{\mathrm{c}}$ and hence the crop ET differ for the two conditions. Thus, we derived crop ET for individual pixels (while treating the irrigated and dryland fields separately) and then averaged the pixels that belong to a particular county to compute county-level crop ET. Finally, countylevel CWP estimates were derived using crop yield and ET data at the same scale. Separating dryland and irrigated yield, ET, and CWP is a rigorous exercise that would require high-resolution datasets for irrigated and non-irrigated areas, and our knowledge is limited. In addition, the datasets, if available, represent a specific point in time and thus cannot be used in an application such as ours, which aims to look at temporal trends. The irrigated and non-irrigated areas are subject to change substantially over a span of 32 years. Due to these constraints, we restricted ourselves to average county-level estimates of these variables to decipher their trends over this period.

\section{Histograms of CWP Frequency Distributions}

A total of 16,520 observation data points for maize and 12,961 observation data points for soybean were used to de- 
velop the frequency distribution histograms (fig. 17). Maize CWP ranged from 0.06 to $4.88 \mathrm{~kg} \mathrm{~m}^{-3}$ with a peak frequency range of 1.2 to $1.3 \mathrm{~kg} \mathrm{~m}^{-3}$. Soybean CWP ranged from 0.05 to $1.17 \mathrm{~kg} \mathrm{~m}^{-3}$ with a peak frequency range of 0.4 to $0.5 \mathrm{~kg}$ $\mathrm{m}^{-3}$. To further investigate the variation in maize and soybean CWP during 1982-2013, the skewness statistic was calculated for each year (table 2) to quantify the variation in frequency distribution over the study period. For most of the years in the study period, the skewness for maize CWP has positive values, which implies that the histogram distribution is more skewed toward lower CWP in those years. For soybean, there are negative values of skewness, signifying that the histogram distribution is more skewed toward higher CWP values in those years.

This study has some limitations, which have to be highlighted for ease of interpretation and for making conclusions. First, our approach considered the irrigated and rainfed yields collectively, as one of the aims was to study all the variables over the complete geographical extent of all nine states. The USDA-NASS provides separate irrigated and rainfed yields only for states with substantial irrigation practices, e.g., Nebraska. We used the average yield statistics from the USDA-NASS, as reported for most of the 834 counties. Similarly, we computed averaged crop water use (ET) for maize and soybean for each county to match with the county-averaged reported crop yields. When computing crop ET via the $K_{\mathrm{c}}$-NDVI approach, it was challenging to separate irrigated and rainfed regions because we could not find any promising database that presented irrigated regions in the U.S. at the desired scale. Moreover, the existing satellite-based datasets were developed for a fixed year and were not well suited for our purpose, as our study focuses on 32 growing seasons (1982-2013), and irrigated areas changed substantially during that period. However, these approaches introduced certain uncertainties into the analysis. The crop yields reported in this study are weighted averages of both dryland (and rainfed) and irrigated fields in a particular county, and the proportion of rainfed and irrigated fields can vary substantially in each state or even within a county, thus affecting the county average. For example, the crop yields reported for Iowa counties are all from rainfed fields because the higher precipitation in the state is sufficient to meet crop water requirements. However, in Nebraska, the amount of precipitation received might not be enough to meet crop water requirements across the state. For instance, precipitation in southeastern Nebraska should generally be sufficient, which indicates that reported county yields in this region are for rainfed fields. In western and central Nebraska, irrigation is necessary to supplement precipitation and meet crop water demands, which indicates that reported crop yields are for a combination of irrigated and dryland fields. Consequently, the statewide average in Nebraska would be lower because of the presence of dryland fields where precipitation is not enough for optimal crop performance. Ideally, such a comparison of precipitation received and crop water use (ET) would be sufficient to segregate irrigated and rainfed cropping regions. However, this is not always the case. In certain regions or years, although the annual or growing season precipitation is sufficient, the timing of the precipitation is often a crucial variable. If the timing of the precipitation does not coincide with the peak water use periods or with periods of sensitivity to water stress in a rainfed crop, it is difficult to maintain stress-free conditions, and irrigation might be necessary. Moreover, in regions with coarse-textured soils, the timing of precipitation may play an important role because the soils might not retain moisture until the peak water use period. Therefore, the proportion of irrigated and rainfed fields in a political unit (county or state) may vary with the region, soil type, and rainfall received in a particular growing season. Hence, direct crop yield comparisons based on political units should be carefully understood and interpreted, especially for counties and states where the proportions of rainfed and irrigated fields vary substantially.

Secondly, the use of NDVI as the vegetation index to estimate $K_{\mathrm{c}}$ data in our study can be questioned in light of various limitations in the use of NDVI for crop monitoring. Some disadvantages with NDVI in landscape studies are related to the nonlinear behavior of ratios, sensitivity to soil background effects, and saturation at moderate to high vegetation densities. Furthermore, the performance of NDVI to indicate crop water status is also subject to question, as it is

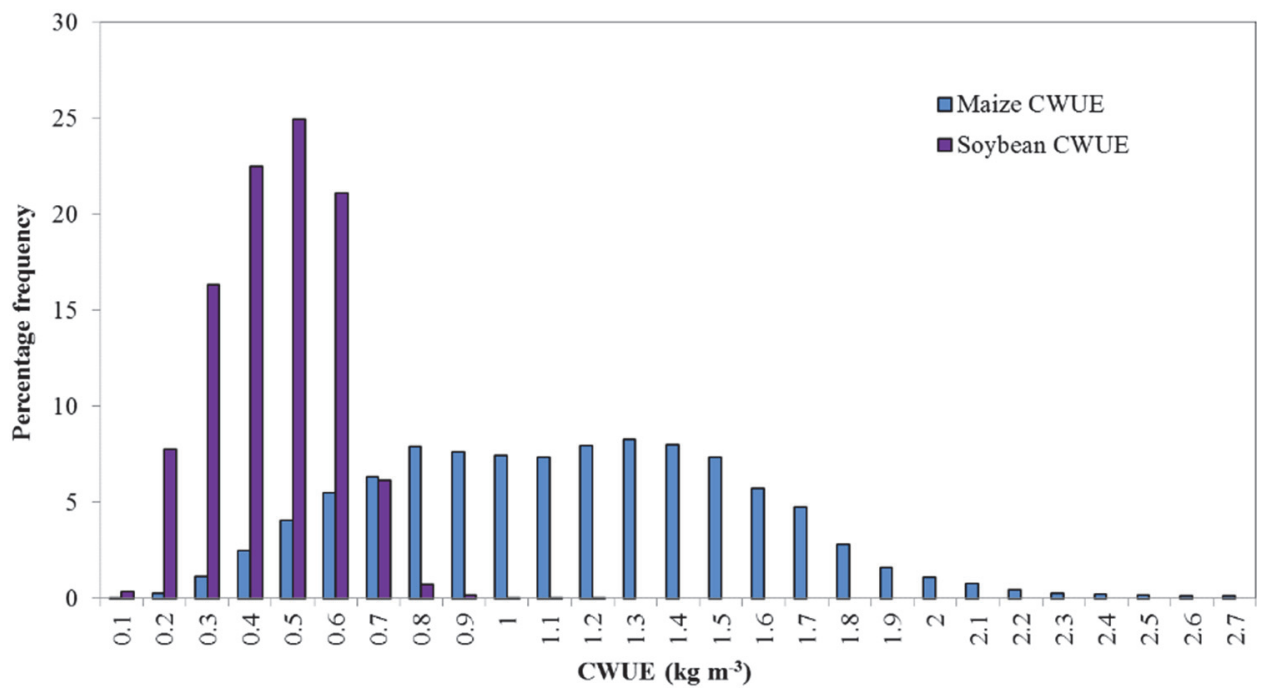

Figure 17. Frequency histograms of county average maize and soybean crop water productivity (CWP) from 1982 to 2013 across the study area. 
does not accurately represent stressed conditions (due to pests, disease, drought, etc.) in both irrigated and rainfed settings.

Finally, concerns can be raised about the accuracy of the two-step approach in producing crop ET estimates in situations where crops experience water stress. Efforts have been made to use NDVI and other vegetation indices to predict $K_{\mathrm{cb}}$ in the dual crop coefficient approach (Bausch and Neale, 1987; Choudhury et al., 1994; Bausch, 1995; Ray and Dadhwal, 2001; Duchemin et al., 2002), which is considered more accurate than the single $K_{\mathrm{c}}$ approach. However, this introduces complexity into the process of ET determination, as several other datasets are needed. For example, datasets on precipitation and irrigation amounts and timing, as well as information on soil water holding capacity, would be required for the calculation of the water stress coefficient $\left(K_{\mathrm{s}}\right)$, which is an arduous task in large-scale and long-term studies. Moreover, it should be understood that using the FAO dual crop coefficient instead of the single $K_{\mathrm{c}}$ approach would involve using tabulated (FAO-56) values for $K_{\mathrm{cb}}$ and $K_{\mathrm{e}}$, which are fixed values in space and time. Contrary to this, our hypothesis in this study stated that $K_{\mathrm{c}}$ varies in both space and time, which is the reason we used NDVI to develop actual site-specific and time-specific $K_{\mathrm{c}}$ estimates. Hence, we selected the FAO single $K_{\mathrm{c}}$ two-step approach to quantify crop water use.

Given that the above issues and concerns are taken into consideration when interpreting the findings, the information provided in this article is valuable for understanding the dynamics in crop productivity indices over large-scale spatial and long-term temporal extents, which otherwise is an extremely difficult task without labor-intensive methodologies. Future efforts in this direction could include the quantification of water use and productivity of major crops in the region at much finer scales using reflectance data from a wide range of satellites (depending on the time scale and resolution) and assessing the performance of various vegetation indices to estimate $K_{\mathrm{c}}$. Special efforts can be undertaken to account for crop water stress by including a larger range of ground truth datasets from geographically distributed sites across the region. Lastly, segregating dryland and irrigated fields is still a challenge, especially in long-term studies that require interannual and long-term changes in their proportion, and should be studied in greater depth.

\section{SUMmARY AND CONCLUSIONS}

The study aimed at quantification, mapping, and analyzing the long-term magnitudes, spatial and temporal trends, and frequency distributions of maize and soybean yield, annual precipitation use efficiency (ANNPUE), growing season precipitation use efficiency (GRSPUE), and crop water productivity (CWP) for the period 1982-2013 in the U.S. Great Plains using multiple public data sources and datasets developed in prior studies.

Considerable spatial variability exists in the crop yields reported for various counties in the region. This is also true for maize and soybean ANNPUE and GRSPUE. Maps were developed depicting long-term county averages of these var- iables to identify regions with high or low magnitudes. The regional average magnitudes of maize and soybean yields were 6.66 and 2.17 ton $\mathrm{ha}^{-1}$, respectively. On a statewide average basis, Iowa had the highest maize yield, followed by Nebraska, Colorado, Kansas, Wyoming, Texas, South Dakota, Oklahoma, and North Dakota. For soybean, the highest statewide average yield was observed for Iowa, followed by Nebraska, Kansas, South Dakota, Texas, North Dakota, and Oklahoma. Crop yields increased from 1982 to 2013, with average rates of increase of 101.4 and $32.8 \mathrm{~kg} \mathrm{ha}^{-1}$ year $^{-1}$ for maize and soybean, respectively. The yield gains were attributed to the application of technological advances in genetic, agronomic, and irrigation practices.

The ANNPUE, GRSPUE, and CWP values were quantified and mapped for the entire study region. The regional average maize ANNPUE, maize GRSPUE, soybean ANNPUE, and soybean GRSPUE were 1.09, 1.90, 0.32, and $0.55 \mathrm{~kg} \mathrm{~m}^{-3}$, respectively. For maize ANNPUE and GRSPUE, the spatial distributions were similar, with Wyoming having the highest magnitude and Oklahoma having the lowest magnitude. For soybean ANNPUE and GRSPUE, Nebraska had the highest magnitude and Oklahoma had the lowest. The CWP values for maize and soybean were averaged for the region and were 1.08 and $0.40 \mathrm{~kg} \mathrm{~m}^{-3}$, respectively. On a statewide average scale, Wyoming had the highest maize CWP, followed by Colorado, Iowa, Nebraska, Kansas, Texas, Oklahoma, South Dakota, and North Dakota. For soybean, Iowa had the highest CWP, followed by Nebraska, Kansas, South Dakota, Texas, North Dakota, and Oklahoma. Primarily due to the increasing crop yields, the ANNPUE, GRSPUE, and CWP also increased for most of the counties. The rates of increase in maize ANNPUE, GRSPUE, and CWP were 0.0174, 0.0316, and $0.0144 \mathrm{~kg}$ $\mathrm{m}^{-3}$ year $^{-1}$, respectively. Similarly, soybean ANNPUE, GRSPUE, and CWP increased at rates of 0.0048, 0.0081, and $0.0047 \mathrm{~kg} \mathrm{~m}^{-3}$ year $^{-1}$, respectively. This information, which included regional averages and spatial and temporal maps, provided insights into the current status and the improvements or declines in the efficiency measures over the region and the study period.

For all variables, the frequency distribution was studied during the study period to observe the inter-annual variation and distribution of the variables. The detailed maps and analyses presented in this study have the potential to enhance the ability of policymakers, agricultural managers and professionals, and state and federal agencies to identify priority areas for careful assessment so that improvements in soil, crop, and irrigation management practices can be allocated or reallocated. This would result in efficient use of freshwater resources for enhancing crop water productivity. The results of this study can also provide useful information on past and current crop production efficiency in terms of yield and water use and can be invaluable for making future projections of crop water productivity in relation to climate change, water use, and crop yield.

\section{ACKNOWLEDGEMENTS}

This study is based on work supported by the USDA National Institute of Food and Agriculture (NIFA) Hatch Pro- 
ject under Project No. NEB-21-167. This study was also supported by grants from the Nebraska Environmental Trust (NET) under Project Agreement No. 13-146 and the Central Platte Natural Resources District (CPNRD) under Grant Agreement No. 38484. As Principal Investigator, Dr. Suat Irmak expresses his appreciation to USDA-NIFA, NET, and CPNRD.

\section{REFERENCES}

Abdullaev, I., \& Molden, D. (2004). Spatial and temporal variability of water productivity in the Syr Darya basin, central Asia. Water Resour. Res., 40(8). https://doi.org/10.1029/2003WR002364

Ali, M. H., \& Talukder, M. S. (2008). Increasing water productivity in crop production: A synthesis. Agric. Water Mgmt., 95(11), 1201-1213. https://doi.org/10.1016/j.agwat.2008.06.008

Amthor, J. S. (1998). Perspective on the relative insignificance of increasing atmospheric $\mathrm{CO} 2$ concentration to crop yield. Field Crops Res., 58(2), 109-127. https://doi.org/10.1016/S03784290(98)00089-6

Bausch, W. C. (1995). Remote sensing of crop coefficients for improving the irrigation scheduling of corn. Agric. Water Mgmt., 27(1), 55-68. http://dx.doi.org/10.1016/03783774(95)01125-3

Bausch, W. C., \& Neale, C. M. (1987). Crop coefficients derived from reflected canopy radiation: A concept. Trans. ASAE, 30(3), 703-709. https://doi.org/10.13031/2013.30463

Brauman, K. A., Siebert, S., \& Foley, J. A. (2013). Improvements in crop water productivity increase water sustainability and food security: A global analysis. Environ. Res. Lett., 8(2), 024030. https://doi.org/10.1088/1748-9326/8/2/024030

Cao, G., Cui, Y., \& Meng, J. (2007). The effect of irrigation systems in spring on grain yield of winter wheat. Chinese Agric. Sci. Bull., 23(3), 466-468.

Carruthers, I., Rosegrant, M. W., \& Seckler, D. (1997). Irrigation and food security in the 21st century. Irrig. Drain. Syst., 11(2), 83-101. https://doi.org/10.1023/a:1005751232728

Chen, C., Wang, E., \& Yu, Q. (2010). Modelling the effects of climate variability and water management on crop water productivity and water balance in the North China Plain. Agric. Water Mgmt., 97(8), 1175-1184. https://doi.org/10.1016/j.agwat.2008.11.012

Choudhury, B. J., Ahmed, N. U., Idso, S. B., Reginato, R. J., \& Daughtry, C. S. (1994). Relations between evaporation coefficients and vegetation indices studied by model simulations. Remote Sens. Environ., 50(1), 1-17. http://dx.doi.org/10.1016/0034-4257(94)90090-6

Duchemin, B., Frappart, F., Maisongrande, P., Magnac, M., Mougenot, B., Chehbouni, A., \& Dedieu, G. (2002). Water budget with phenology derived from optical satellite data. Proc. 1st Intl. Symp. Recent Advances in Quantitative Remote Sensing. Valencia, Spain: University of Valencia.

Evans, L. T. (1997). Adapting and improving crops: The endless task. Phil. Trans. Royal Soc. London B, 352(1356), 901-906. https://doi.org/10.1098/rstb.1997.0069

Evett, S. R., Howell, T. A., Schneider, A. D., Upchurch, D. R., \& Wanjura, D. F. (1996). Canopy temperature based automatic irrigation control. Proc. Intl. Conf. Evapotranspiration and Irrigation Scheduling (pp. 207-213). St. Joseph, MI: ASAE.

Ewert, F., Rodriguez, D., Jamieson, P., Semenov, M. A., Mitchell, R. A., Goudriaan, J., ... Villalobos, F. (2002). Effects of elevated $\mathrm{CO}_{2}$ and drought on wheat: Testing crop simulation models for different experimental and climatic conditions. Agric. Ecosyst. Environ., 93(1), 249-266. https://doi.org/10.1016/S01678809(01)00352-8
Fahong, W., Xuqing, W., \& Sayre, K. (2004). Comparison of conventional, flood irrigated, flat planting with furrow irrigated, raised bed planting for winter wheat in China. Field Crops Res., 87(1), 35-42. https://doi.org/10.1016/j.fcr.2003.09.003

Falkenmark, M., \& Rockstrom, J. (2004). Balancing water for humans and nature: The new approach in ecohydrology. Abingdon, UK: Earthscan.

FAO. (1994). FAO production yearbook 1993, Vol. 47. Rome, Italy: United Nation FAO.

Farahani, H. J., Peterson, G. A., \& Westfall, D. G. (1998). Dryland cropping intensification: A fundamental solution to efficient use of precipitation. Adv. Agron., 64, 197-223.

Fengrui, L., Songling, Z., \& Geballe, G. T. (2000). Water use patterns and agronomic performance for some cropping systems with and without fallow crops in a semi-arid environment of northwest China. Agric. Ecosyst. Environ., 79(2), 129-142.

Garabet, S., Wood, M., \& Ryan, J. (1998). Nitrogen and water effects on wheat yield in a Mediterranean-type climate: I. Growth, water use, and nitrogen accumulation. Field Crops Res., 57(3), 309-318. https://doi.org/10.1016/S0378-4290(98)00075-6

Govaerts, B., Sayre, K. D., Ceballos-Ramirez, J. M., Luna-Guido, M. L., Limon-Ortega, A., Deckers, J., \& Dendooven, L. (2006). Conventionally tilled and permanent raised beds with different crop residue management: Effects on soil $\mathrm{C}$ and $\mathrm{N}$ dynamics. Plant Soil, 280(1), 143-155. https://doi.org/10.1007/s11104-0052854-7

Greb, B. W. (1979). Reducing drought effects on cropland in the west-central Great Plains. Agricultural Information Bulletin No. 420. Washington, DC: USDA.

Greb, B. W., Smika, D. E., \& Black, A. L. (1967). Effect of straw mulch rates on soil water storage during summer fallow in the Great Plains. SSSA J., 31(4), 556-559. https://doi.org/10.2136/sssaj1967.03615995003100040034x

Guo, R., Lin, Z., Mo, X., \& Yang, C. (2010). Responses of crop yield and water use efficiency to climate change in the North China Plain. Agric. Water Mgmt., 97(8), 1185-1194. https://doi.org/10.1016/j.agwat.2009.07.006

Hatfield, J. L., Sauer, T. J., \& Prueger, J. H. (2001). Managing soils to achieve greater water use efficiency. Agron. J., 93(2), 271280. https://doi.org/10.2134/agronj2001.932271x

Holt, R. F., \& Timmons, D. R. (1968). Influence of precipitation, soil water, and plant population interactions on corn grain yields. Agron. J., 60(4), 379-381. https://doi.org/10.2134/agronj1968.00021962006000040014x

Howell, T. A. (1990). Relationships between crop production and transpiration, evapotranspiration, and irrigation. In Irrigation of agricultural crops (pp. 391-434). Agronomy Monograph No. 30. Madison, WI: ASA-CSSA-SSSA.

Howell, T. A., Evett, S. R., Tolk, J. A., Schneider, A. D., \& Steiner, J. L. (1996). Evapotranspiration of corn: Southern High Plains. Proc. Intl. Conf. Evapotranspiration and Irrigation Scheduling (pp. 158-166). St. Joseph, MI: ASAE.

Howell, T. A., Yazar, A., Schneider, A. D., Dusek, D. A., \& Copeland, K. S. (1995). Yield and water use efficiency of corn in response to LEPA irrigation. Trans. ASAE, 38(6), 1737-1747. https://doi.org/10.13031/2013.28001

Hsiao, T. C., Heng, L., Steduto, P., Rojas-Lara, B., Raes, D., \& Fereres, E. (2009). Aquacrop: The FAO crop model to simulate yield response to water: III. Parameterization and testing for maize. Agron. J., 101(3), 448-459. https://doi.org/10.2134/agronj2008.0218s

Immerzeel, W. W., Gaur, A., \& Zwart, S. J. (2008). Integrating remote sensing and a process-based hydrological model to evaluate water use and productivity in a south Indian catchment. Agric. Water Mgmt., 95(1), 11-24. https://doi.org/10.1016/j.agwat.2007.08.006 
Irmak, S. (2010). Nebraska water and energy flux measurement, modeling, and research network (NEBFLUX). Trans. ASABE, 53(4), 1097-1115. https://doi.org/10.13031/2013.32600

Irmak, S. (2015a). Interannual variation in long-term center-pivot irrigated maize evapotranspiration (ET) and various water productivity response indices: Part I. Grain yield, actual and basal evapotranspiration, irrigation-yield production functions, evapotranspiration-yield production functions, and yield response factors. J. Irrig. Drain. Eng., 141(5), 1-17. https://doi.org/10.1061/(ASCE)IR.1943-4774.0000825

Irmak, S. (2015b). Inter-annual variation in long-term center-pivot irrigated maize evapotranspiration (ET) and various water productivity response indices: Part II. Irrigation water use efficiency (IWUE), crop (WUE), evapotranspiration (WUE), irrigation-evapotranspiration use efficiency, and precipitation use efficiency. J. Irrig. Drain. Eng., 141(5), 1-11. https://doi.org/10.1061/(ASCE)IR.1943-4774.0000826

Irmak, S., \& Djaman, K. (2016). Effects of planting date and density on plant growth, yield, evapotranspiration, and water productivity of subsurface drip-irrigated and rainfed maize.

Irmak, S., \& Sharma, V. (2015). Large-scale and long-term trends and magnitudes in irrigated and rainfed maize and soybean water productivity: Grain yield and evapotranspiration frequency, crop water use efficiency, and production functions. Trans. ASABE, 58(1), 103-120. https://doi.org/10.13031/trans.58.10784

Irmak, S., Burgert, M., Yang, H., Cassman, K., Walters, D., Rathje, W., \& Brunkhorst, K. (2012). Large-scale on-farm implementation of soil moisture-based irrigation management strategies for increasing maize water productivity. Trans. ASABE, 55(3), 881-894. https://doi.org/10.13031/2013.41521

Irmak, S., Kabenge, I., Skaggs, K. E., \& Mutiibwa, D. (2012). Trend and magnitude of changes in cli-mate variables and reference evapotranspiration over 116-yr period in the platte river basin, central Nebraska USA. J. Hydrol., 420, 228-244. https://doi.org/10.1016/j.jhydrol.2011.12.006

Irmak, S., Specht, J., Odhiambo, L., Rees, J. M., \& Cassman, K. (2014). Soybean yield, evapotranspiration, water productivity, and soil water extraction response to subsurface drip irrigation and fertigation. Trans. ASABE, 57(3), 729-748. https://doi.org/10.13031/trans.57.10085

Karam, F., Masaad, R., Sfeir, T., Mounzer, O., \& Rouphael, Y. (2005). Evapotranspiration and seed yield of field-grown soybean under deficit irrigation conditions. Agric. Water Mgmt., 75(3), 226-244. https://doi.org/10.1016/j.agwat.2004.12.015

Keller, A., \& Seckler, D. (2005). Limits to the productivity of water in crop production. California Water Plan Update 2005, Vol. 4 (pp. 177-197). Sacramento, CA: California Department of Water.

Kendall, M. (1975). Multivariate analysis. London, UK: Charles Griffin Co.

Kukal, M., \& Irmak, S. (2016a). Long-term patterns of air temperatures, daily temperature range, precipitation, grassreference evapotranspiration, and aridity index in the USA Great Plains: Part I. Spatial trends. J. Hydrol., 542, 953-977. https://doi.org/10.1016/j.jhydrol.2016.06.006

Kukal, M., \& Irmak, S. (2016b). Long-term patterns of air temperatures, daily temperature range, precipitation, grassreference evapotranspiration and aridity index in the USA Great Plains: Part II. Temporal trends. J. Hydrol., 542, 978-1001. https://doi.org/10.1016/j.jhydrol.2016.06.008

Kukal, M., Kilic, A., \& Irmak, S. (2017). Long-term spatial and temporal maize and soybean evapotranspiration trends derived from ground and satellite-based datasets over the USA Great Plains. J. Irrig. Drain.Eng., (in press).

Landau, S., Mitchell, R. A., Barnett, V., Colls, J. J., Craigon, J.,
Moore, K. L., \& Payne, R. W. (1998). Testing winter wheat simulation models' predictions against observed UK grain yields. Agric. Forest Meteorol., 89(2), 85-99. http://dx.doi.org/10.1016/S0168-1923(97)00069-5

Lang, A. L., Pendleton, J. W., \& Dungan, G. H. (1956). Influence of population and nitrogen levels on yield and protein and oil contents of nine corn hybrids. Agron. J., 48(7), 284-289. https://doi.org/10.2134/agronj1956.00021962004800070002x

Li, F. P., Li, Q. X., \& Wang, Z. L. (2009). Analysis of agricultural water saving in Hai basin based on remote sensing water productivity. Proc. Intl. Symp. Hai Basin Integrated Water and Environment Management (pp. 413-418). Beijing, China: Orient Academic Forum.

Li, H., Zheng, L., Lei, Y., Li, C., Liu, Z., \& Zhang, S. (2008). Estimation of water consumption and crop water productivity of winter wheat in North China Plain using remote sensing technology. Agric. Water Mgmt., 95(11), 1271-1278. https://doi.org/10.1016/j.agwat.2008.05.003

Limon-Ortega, A., Sayre, K. D., \& Francis, C. A. (2000). Wheat and maize yields in response to straw management and nitrogen under a bed planting system. Agron. J., 92(2), 295-302. https://doi.org/10.2134/agronj2000.922295x

Liu, J., Wiberg, D., Zehnder, A. J., \& Yang, H. (2007). Modeling the role of irrigation in winter wheat yield, crop water productivity, and production in China. Irrig. Sci., 26(1), 21-33. https://doi.org/10.1007/s00271-007-0069-9

Liu, J., Zehnder, A. J., \& Yang, H. (2008). Drops for crops: Modelling crop water productivity on a global scale. Global NEST J., 10(3), 295-300.

Lobell, D. B., \& Asner, G. P. (2003). Climate and management contributions to recent trends in U.S. agricultural yields. Science, 299(5609), 1032-1032. https://doi.org/10.1126/science.1078475

Lutz, J. A., Camper, H. M., \& Jones, G. D. (1971). Row spacing and population effects on corn yields. Agron. J., 63(1), 12-14. https://doi.org/10.2134/agronj1971.00021962006300010005x

Mainuddin, M., \& Kirby, M. (2009). Spatial and temporal trends of water productivity in the lower Mekong River basin. Agric. Water Mgmt., 96(11), 1567-1578. https://doi.org/10.1016/j.agwat.2009.06.013

Mann, H. B. (1945). Nonparametric tests against trend. Econometrica, 13(3), 245-259. https://doi.org/10.2307/1907187

McGee, E. A., Peterson, G. A., \& Westfall, D. G. (1997). Water storage efficiency in no-till dryland cropping systems. J. Soil Water Cons., 52(2), 131-136. Retrieved from http://www.jswconline.org/content/52/2/131.abstract

Mo, X., Liu, S., Lin, Z., Xu, Y., Xiang, Y., \& McVicar, T. R. (2005). Prediction of crop yield, water consumption, and water use efficiency with a SVAT-crop growth model using remotely sensed data on the North China Plain. Ecol. Model., 183(2), 301322. https://doi.org/10.1016/j.ecolmodel.2004.07.032

Müller, E., Wildhagen, H., Quintern, M., Heb, J., Wichern, F., \& Joergensen, R. G. (2009). Spatial patterns of soil biological and physical properties in a ridge tilled and a ploughed Luvisol. Soil Tillage Res., 105(1), 88-95. https://doi.org/10.1016/j.still.2009.05.011

Mutiibwa, D., \& Irmak, S. (2013). AVHRR-NDVI-based crop coefficients for analyzing long-term trends in evapotranspiration in relation to changing climate in the U.S. High Plains. Water Resour. Res., 49(1), 231-244. https://doi.org/10.1029/2012WR012591

Niu, S., Yuan, Z., Zhang, Y., Liu, W., Zhang, L., Huang, J., \& Wan, S. (2005). Photosynthetic responses of C3 and C4 species to seasonal water variability and competition. J. Exp. Bot., 56(421), 2867-2876. https://doi.org/10.1093/jxb/eri281

Norwood, C. A. (2000). Water use and yield of limited-irrigated and dryland corn. SSSA J., 64(1), 365-370. 
https://doi.org/10.2136/sssaj2000.641365x

Payero, J. O., Melvin, S. R., \& Irmak, S. (2005). Response of soybean to deficit irrigation in the semi-arid environment of west-central Nebraska. Trans. ASAE, 48(6), 2189-2203. https://doi.org/10.13031/2013.20105

Payero, J. O., Tarkalson, D. D., Irmak, S., Davison, D., \& Petersen, J. L. (2009). Effect of timing of a deficit-irrigation allocation on corn evapotranspiration, yield, water use efficiency, and dry mass. Agric. Water Mgmt., 96(10), 1387-1397. https://doi.org/10.1016/j.agwat.2009.03.022

Perry, C. (2007). Efficient irrigation; inefficient communication; flawed recommendations. Irrig. Drainage, 56(4), 367-378.

Perry, C., Steduto, P., Allen, R. G., \& Burt, C. M. (2009). Increasing productivity in irrigated agriculture: Agronomic constraints and hydrological realities. Agric. Water Mgmt., 96(11), 1517-1524. https://doi.org/10.1016/j.agwat.2009.05.005

Peterson, G. A., \& Westfall, D. G. (2004). Managing precipitation use in sustainable dryland agroecosystems. Ann. Appl. Biol., 144(2), 127-138. https://doi.org/10.1111/j.17447348.2004.tb00326.x

Ray, D. K., Ramankutty, N., Mueller, N. D., West, P. C., \& Foley, J. A. (2012). Recent patterns of crop yield growth and stagnation. Nature Commun., 3, 1293. https://doi.org/10.1038/ncomms2296

Ray, S. S., \& Dadhwal, V. K. (2001). Estimation of crop evapotranspiration of irrigation command area using remote sensing and GIS. Agric. Water Mgmt., 49(3), 239-249. https://doi.org/10.1016/S0378-3774(00)00147-5

Reynolds, M. P., Rajaram, S., \& Sayre, K. D. (1999). Physiological and genetic changes of irrigated wheat in the post-green revolution period and approaches for meeting projected global demand. Crop Sci., 39(6), 1611-1621. https://doi.org/10.2135/cropsci1999.3961611x

Rosegrant, M. W., Cai, X., \& Cline, S. A. (2002). Global water outlook to 2025: Averting an impending crisis. Colombo, Sri Lanka: International Water Management Institute.

Rossum, S., \& Lavin, S. (2000). Where are the Great Plains? A cartographic analysis. Prof. Geographer, 52(3), 543-552. https://doi.org/10.1111/0033-0124.00245

Scott, H. D., Ferguson, J. A., \& Wood, L. S. (1987). Water use, yield, and dry matter accumulation by determinate soybean grown in a humid region. Agron. J., 79(5), 870-875. https://doi.org/10.2134/agronj1987.00021962007900050023x

Sen, P. K. (1968). Estimates of the regression coefficient based on Kendall's tau. J. American Stat. Assoc., 63(324), 1379-1389. https://doi.org/10.1080/01621459.1968.10480934

Sexton, B. T., Moncrief, J. F., Rosen, C. J., Gupta, S. C., \& Cheng, H. H. (1996). Optimizing nitrogen and irrigation inputs for corn based on nitrate leaching and yield on a coarse-textured soil. $J$.
Environ. Qual., 25(5), 982-992. https://doi.org/10.2134/jeq1996.00472425002500050008x

Sharma, A., Sankar, G. R., Arora, S., Gupta, V., Singh, B., Kumar, J., \& Mishra, P. K. (2013). Analyzing rainfall effects for sustainable rainfed maize productivity in foothills of northwest Himalayas. Field Crops Res., 145, 96-105. https://doi.org/10.1016/j.fcr.2013.02.013

Smika, D. E. (1990). Fallow management practices for wheat production in the central Great Plains. Agron. J., 82(2), 319-323. https://doi.org/10.2134/agronj1990.00021962008200020029x

Stanhill, G. (1986). Water use efficiency. Adv. Agron., 39, 53-85.

Steduto, P., Hsiao, T. C., Raes, D., \& Fereres, E. (2009). AquaCrop: The FAO crop model to simulate yield response to water: I. Concepts and underlying principles. Agron. J., 101(3), 426-437.

Stone, L. R., Gwin, R. E., Gallagher, P. J., \& Hattendorf, M. J. (1987). Dormant-season irrigation: Grain yield, water use, and water loss. Agron. J., 79(4), 632-636. https://doi.org/10.2134/agronj1987.00021962007900040010x

Tolk, J. A., Howell, T. A., \& Evett, S. R. (1999). Effect of mulch, irrigation, and soil type on water use and yield of maize. Soil Tillage Res., 50(2), 137-147. https://doi.org/10.1016/S01671987(99)00011-2

Tollenaar, M., \& Wu, J. (1999). Yield improvement in temperate maize is attributable to greater stress tolerance. Crop Sci., 39(6), 1597-1604. https://doi.org/10.2135/cropsci1999.3961597x

Turner, N. C. (2004). Agronomic options for improving rainfall-use efficiency of crops in dryland farming systems. J. Exp. Bot., 55(407), 2413-2425. https://doi.org/10.1093/jxb/erh154

Wang, T.-C., Wei, L., Wang, H.-Z., Ma, S.-C., \& Ma, B. L. (2011). Responses of rainwater conservation, precipitation-use efficiency, and grain yield of summer maize to a furrow-planting and straw-mulching system in northern China. Field Crops Res., 124(2), 223-230. https://doi.org/10.1016/j.fcr.2011.06.014

Yan, N., \& Wu, B. (2014). Integrated spatial-temporal analysis of crop water productivity of winter wheat in Hai basin. Agric. Water Mgmt., 133, 24-33. https://doi.org/10.1016/j.agwat.2013.11.001

Yazar, A., Howell, T. A., Dusek, D. A., \& Copeland, K. S. (1999). Evaluation of crop water stress index for LEPA irrigated corn. Irrig. Sci., 18(4), 171-180. https://doi.org/10.1007/s002710050059

Yuan, M., Zhang, L., Gou, F., Su, Z., Spiertz, J. H., \& van der Werf, W. (2013). Assessment of crop growth and water productivity for five C3 species in semi-arid Inner Mongolia. Agric. Water Mgmt., 122, 28-38. https://doi.org/10.1016/j.agwat.2013.02.006

Zhang, X., Pei, D., \& Hu, C. (2003). Conserving groundwater for irrigation in the North China Plain. Irrig. Sci., 21(4), 159-166. https://doi.org/10.1007/s00271-002-0059-x 